\title{
Outcome of burn care: the mortality perspective
}

\author{
Laura Pompermaier
}

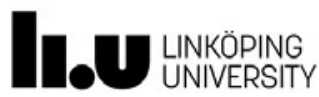

\author{
Division of Hand and Plastic Surgery \\ Department of Clinical and Experimental Medicine \\ Faculty of Medicine and Health Sciences
}

SE- 58185 Linköping, Sweden

Linköping 2017 


\section{Supervisor}

Folke Sjöberg, MD, PhD, Professor

Department of Clinical and Experimental Medicine, Faculty of Medicine and Health Sciences

Linköping University, Sweden

\section{Opponent}

Jyrki Vuola, MD, PhD, Associate Professor

Department of Plastic Surgery, Faculty of Medicine, Helsinki University, Finland

(C) Laura Pompermaier, 2017

Illustration on the cover: "The phoenix rises from its ashes" by Rita Pancheri, 2017

Printed by LIU-Tryck, Linköping, Sweden, 2017.

Previously published articles (paper I, II, and III) have been reprinted with the permission of the copyright holders.

ISBN 978-91-7685-414-3

ISSN 0345-0082 
To the victims of burns 
When I was a child I wanted to heal the cherry trees

I believed they were wounded because of their red fruits

Their health had left them for me

together with the snow-flowers that they had lost.

It was a dream, but it did not disappear
for this I swore I would be a doctor
and not for a god and not even for play;
for the cherry trees would return in bloom,
for the cherry trees would return in bloom.

And when I was finally doctor

I did not betray the child for the man,

and they came in so many and they were called "people"

sick cherry trees in every season.

Fabrizio De André ( "Un medico”) 
Da bambino volevo guarire i ciliegi

quando rossi di frutti li credevo feriti

la salute per me li aveva lasciati

coi fiori di neve che avevan perduti.

Un sogno, fu un sogno ma non durò poco

per questo giurai che avrei fatto il dottore

e non per un dio ma nemmeno per gioco:

perché i ciliegi tornassero in fiore,

perché i ciliegi tornassero in fiore.

E quando dottore lo fui finalmente

non volli tradire il bambino per l'uomo

e vennero in tanti e si chiamavano "gente"

ciliegi malati in ogni stagione.

Fabrizio De André ( “Un medico”)

Translation: Laura Pompermaier 



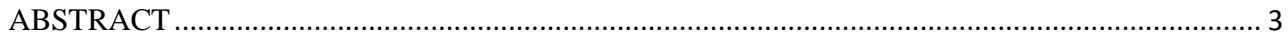

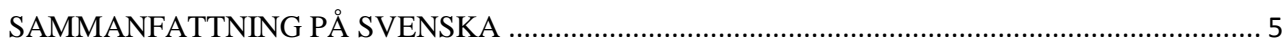

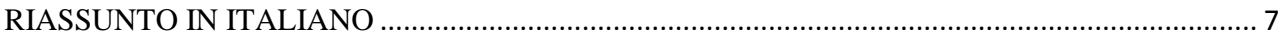

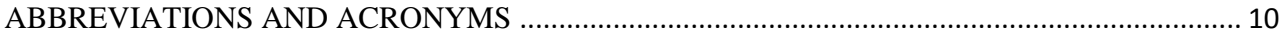

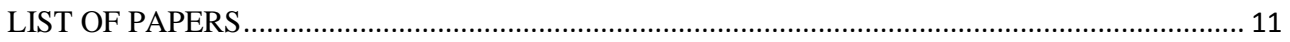

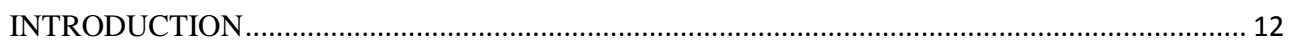

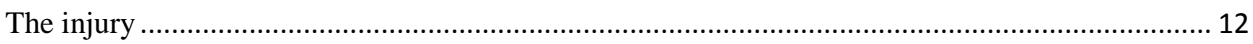

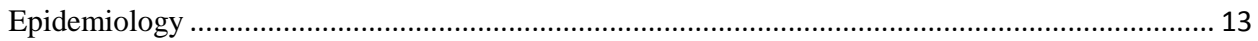

Outcome measures in burn care from the perspective of mortality................................................ 16

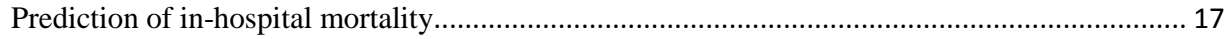

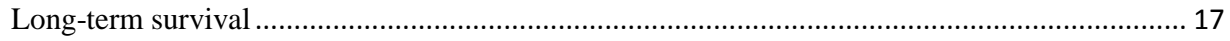

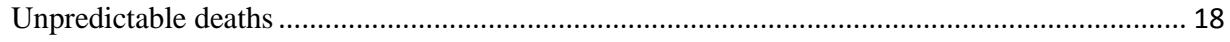

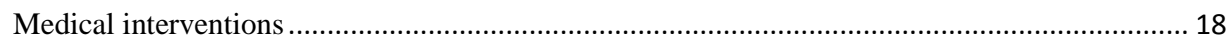

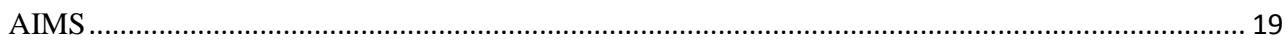

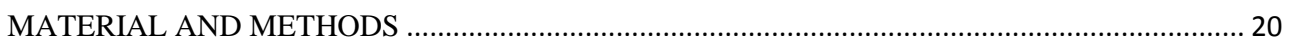

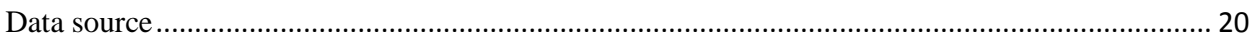

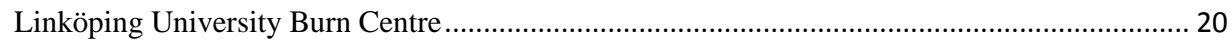

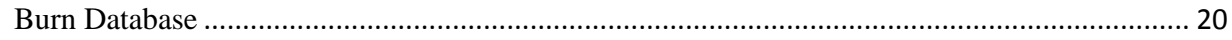

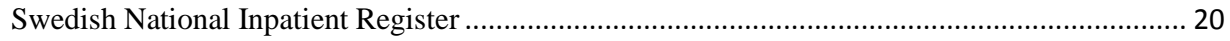

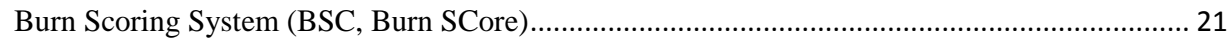

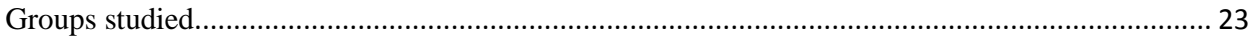

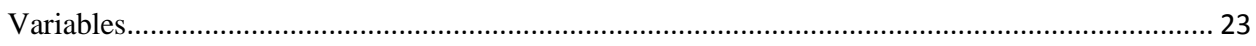

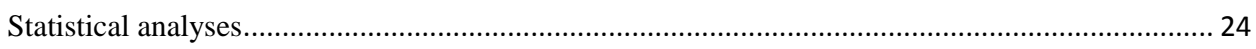

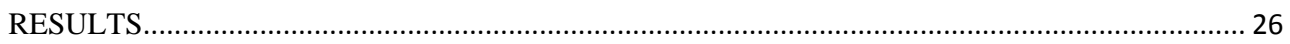

Effect of coexisting morbidity on in-hospital mortality (paper I) .................................................. 26 
Effect of burns on long-term survival (paper II)

Deaths in the group with Baux scores of less than 100 (paper III) ............................................... 32

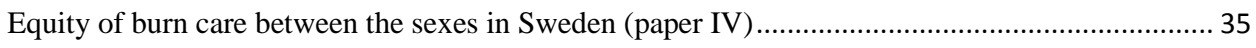

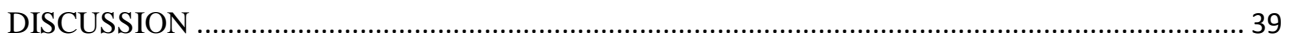

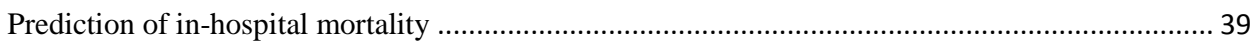

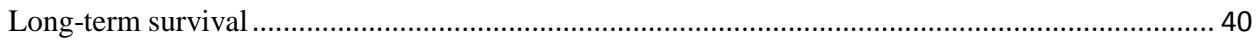

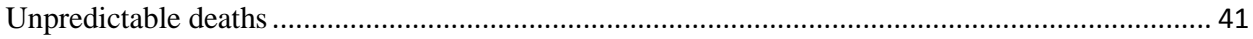

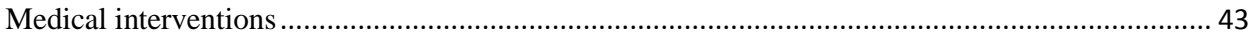

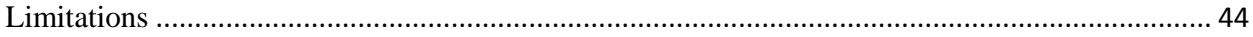

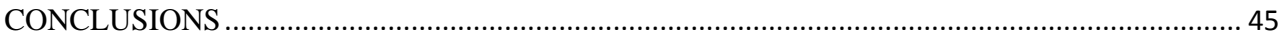

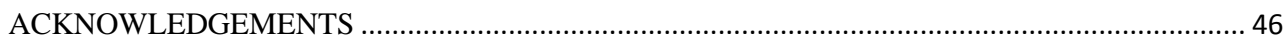

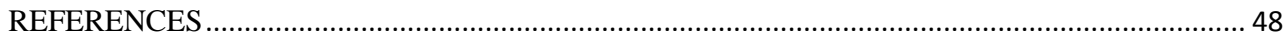




\section{ABSTRACT}

Background: Despite the improvements in burn care during the last decades, burns remain catastrophic for the patients and a challenge for the care-givers. The early outcome of burn care is to assess its quality and to improve it, but the crucial outcome is mortality, which is the main focus of this thesis. In particular, I address questions about mortality that have arisen from working with burned patients and that can have clinical consequences: the impact of preexisting medical conditions; long-term survival; the causes of unexpected deaths; and the possible differences between sexes in the provision of resources.

Patients with burns share the fact that the time of their injury is known, its severity can be quantified from the size of the burn, and the care is relatively standardised. The analysis of outcome among burned patients treated at a single burn centre may therefore be of general value to others who treat burns.

Methods: We retrospectively analysed data that had been collected prospectively (the burn unit database) from patients with burns admitted consecutively to a national burn centre in Sweden during the last 25 years.

Results: Age and percentage of total body surface area burned (TBSA \%) affected the inhospital mortality, whereas pre-existing medical conditions did not influence the prediction of outcome (Paper I). After discharge, both age and the presence of full thickness burns reduced the long-term survival, whereas the extent of the burn (TBSA \%) did not (Paper II). Most patients with moderate burns who die in hospital despite a good prognosis, die for reasons other than the burn (Paper III). Previously, it has been shown that sex is not an independent factor for mortality during burn care; in this thesis we show that the sex of the patients did not affect the number of medical interventions given either (Paper IV).

Conclusion: The addition of "coexisting condition" to a mortality model based on age and size of burn does not improve its predictive value; rather, the factor "age" is sufficient to adjust for comorbidity in the assessment of a burn and its outcome (Paper I).

If patients with burns survive, the long-term prognosis is good. The effect of age is the one that governs survival, whereas the effect of the extent of the burn ends when the patient is discharged (Paper II). 
The in-hospital mortality during burn care is low, but some patients die for reasons other than the actual burn (Paper III).

In a centre where the mortality is independent of the sex of the patient, the provision of medical interventions is also equal between men and women (Paper IV). 


\section{SAMMANFATTNING PÅ SVENSKA}

Dödligheten efter brännskador har minskat under de senaste årtiondena, likväl kvarstår målet att ytterligare minska risken att avlida.

Syftet med denna avhandling var att studera prognosen efter brännskador, och i synnerhet att analysera dödligheten ur olika perspektiv.

De modeller som brukar användas inom brännskadevård för att förutse dödlighet baseras framför allt på brännskadeyta och ålder. Det är emellertid oklart huruvida patientens samsjuklighet påverkar prognosen, och huruvida åldern kan ersätta uppgifter om samsjukligheten. I det första arbetet har detta undersökts genom analys av befintliga vårdregisterdata i Sverige. Att addera information om samsjukligheten till en modell baserat på ålder och brännskadeyta gav inte säkrare förutsägelser.

En återkommande fråga inom brännskadevården har varit huruvida patienter som överlever tiden på sjukhus har förkortad långsiktig överlevnad. I det andra arbetet har detta undersökts genom en uppföljning av samtliga patienter som behandlats vid det nationella brännskadecentrat i Linköping. Resultaten visar att skadans svårighetsgrad (brännskadeytan) inte påverkar hur länge patienterna lever efter utskrivning, medan effekten av ålder är avgörande för överlevnaden på lång sikt.

Det är ovanligt att patienter som vårdas på sjukhus för brännskador avlider. En viktig observation som gjorts i detta sammanhang är att bland dem som dör under dessa omständigheter återfinns individer vars dödsorsak inte är relaterad till själva brännskadan. Detta gäller särskilt för dem som dör trots att skadeutbredningen är relativt sett liten. Fokus för det tredje arbetet var att undersöka vilka dödsorsaker som är relevanta för gruppen i fråga. Resultaten visar att en inte oväsentlig del av dödsfallen var orsakade av andra faktorer än de som är direkt kopplade till själva brännskadan, exempelvis hjärnblödning eller hjärtinfarkt.

Det är väl dokumenterat att ojämlikhet mellan könen ofta föreligger vid medicinsk vård med en diskriminering för kvinnor både avseende resursallokering och utfall (dödlighet). Detta finns visat inom olika sektorer, till exempel finns det visat att mortalitetsutfallet är lika mellan män och kvinnor inom allmän svensk intensivvård men att män får fler behandlingsinsatser än kvinnor. Studier från olika brännskadecentra (USA, Australien, Indien) har visat att risken att 
avlida på sjukhus efter en brännskada är högre för kvinnliga patienter. I motsats till detta finns resultat från en studie vid Brännskadecentrum i Linköping där ingen skillnad i överlevnad kunde påvisas efter justering för skadans storlek och patienternas ålder. I det fjärde arbetet har resursfördelning undersökts ur ett könsperspektiv. Validerade metoder för att mäta vårdinterventioner har använts. I linje med tidigare resultat, med lika överlevnad mellan könen, visade även denna studie att ingen skillnad i resursfördelning mellan könen kunde påvisas.

Sammanfattningsvis visar fynden i denna avhandling att risken av dö av brännskador ökar med åldern och brännskadeytans storlek, och att addering av samsjuklighet inte ger säkrare förutsägelser därutöver. Vidare, att den långsiktiga prognosen är god för de brännskadepatienter som överlever vårdtiden på sjukhus. En inte oväsentlig del av dödsfallen som sker under vårdtiden är orsakade av andra faktorer än de som är direkt kopplade till själva brännskadan. Slutligen har vi visat att behandlingen av manliga och kvinnliga patienter vid ett nationellt brännskadecentrum är jämlik med avseende på resursfördelning och överlevnad.

Slutsatserna som presenteras i denna avhandling bör beaktas vid behandling av brännskadepatienter: data stödjer således ytterligare att aktiv behandling bör erbjudas alla som har en rimlig chans att överleva beräknat utifrån de prediktioner som kan göras med de prediktionsmodeller som presenterats. Denna konklusion är mycket viktig sett ur ett behandlingsperspektiv för denna patientgrupp.

Prognostiska modeller avseende mortalitetsprediktion optimeras om dödsfall med dödsorsaker som inte är relaterade till brännskadan tas bort vid analysen. Vid ett brännskadecentrum där könsjämlik behandling av brännskadepatienter tillämpas, påverkar patientens kön inte utfallet. Detta resultat är glädjande men samtidigt unikt, sett ur ett övergripande vårdperspektiv. 


\section{RIASSUNTO IN ITALIANO}

Questa tesi tratta del rischio di morte in seguito ad ustioni ed affronta, con approccio scientifico, alcune domande sollevate frequentemente da pazienti e da addetti ai lavori.

In particolare:

I. La presenza di altre malattie a prescindere dall'ustione (diabete, nefropatie, alcolismo, etc.) peggiora la prognosi del paziente?

II. L'essere sopravvissuto ad un'ustione riduce l'aspettativa di vita dopo la dimissione dall'ospedale?

III. Qual è la causa di morte in quei (rari) pazienti che muoiono con ustioni di modesta entità?

IV. Il sesso del paziente influenza le cure prestate durante il ricovero ed, in tal caso, qual è l'effetto sulla prognosi?

Spesso avevamo risposto a questi interrogativi di interesse clinico basandoci sull'esperienza o su luoghi comuni accettati acriticamente. Con questa tesi abbiamo cercato con metodo scientifico delle risposte di valore generale, analizzando i dati raccolti durante l'ultimo ventennio sui pazienti ricoverati a causa di traumi termici al Centro Nazionale Grandi Ustioni dell`Università di Linköping.

In Svezia, come negli altri paesi a reddito medio-alto, il tasso di mortalità in seguito ad ustioni è diminuito notevolmente negli ultimi anni, tuttavia l'obbiettivo principale tra gli addetti ai lavori rimane quello di diminuire ulteriormente la mortalità.

L'identificazione precoce di pazienti ad alto rischio di morte fornisce un mezzo utile per migliorarne la prognosi. A tale proposito sono stati sviluppati numerosi modelli matematici in grado di calcolare la probabilità di morte in seguito ad ustioni, basati principalmente sull’età del paziente e sull' estensione dell'ustione. Infatti, è intuitivamente comprensibile che il rischio di morire aumenti con l'età del paziente e la gravità dell'ustione.

Nel nostro primo studio abbiamo aggiunto ad un modello prognostico basato su età e superficie corporea ustionata informazioni sulle malattie già presenti nel paziente prima dell ustione. Contrariamente a quanto ipotizzato, la presenza di altre malattie negli ustionati non ne aumenta la probabilità di morte. 
Nel nostro secondo studio abbiamo seguito i pazienti sopravvissuti all'ustione dopo la dimissione dal nostro Centro ed abbiano dimostrato che l'ustione in se' non ne accorcia la vita ne’a breve termine (nei 30 giorni seguenti la dimissione), ne’a lungo termine.

È piuttosto inusuale che pazienti con ustioni di modesta gravitá muioiano durante il ricovero ospedaliero. Nel nostro terzo studio abbiamo dimostrato che la principale cause di morte tra questi pazienti non è correlata all'ustione in se', ma ad altre patologie indipendenti dal trauma termico, quali l'ictus o l'infarto miocardico.

A livello internazionale è stato ampiamente documentato un impari impiego delle cure mediche tra i sessi, a discapito delle donne. Questa disparità riguarda principalmente la diversa allocazione delle risorse terapeutiche, ma ha conseguenze negative sul'esito finale della cura. Studi provenienti da diversi centri per la terapia delle grandi ustioni (USA, Australia, India) hanno dimostrato che il rischio di morte in ospedale è maggiore per le pazienti femmine. In contrasto con questo, una precedente ricerca svolta presso il nostro centro non ha mostrato alcuna differenza nella sopravvivenza tra uomini e donne. Anche tra i pazienti della terapia intensiva generale svedese la mortalità è simile per entrambi i sessi, nonostante gli uomini ricevano più trattamenti rispetto alle donne. Questa osservazione apre le porte ad un ovvia domanda, e cioè: se le donne ricevessero le stesse attenzioni degli uomini morirebbero esse su scala minore? In linea con i risultati riguardanti la mortalità precedentemente pubblicati dal nostro centro, col nostro quarto studio abbiamo dimostrato che non esiste alcuna disparità tra i sessi nella distribuzione delle risorse.

In sintesi, con questa tesi abbiamo dimostrato che:

i. $\quad$ i fattori che maggiormente influenzano la prognosi in caso di ustione sono l'età del paziente e l'area corporea ustionata; la presenza di altre patologie non aumenta significativamente il rischio di morte.

ii. L'essere sopravvissutto ad un'ustione non riduce l'aspettativa di vita dopo la dimissione dall’ospedale.

iii. Una percentuale non indifferente delle morti che si verificano durante il periodo di cura per ustioni di modesta gravità è causata da fattori indipendenti dall'ustione stessa.

iv. Uomini e donne nel nostro centro ricevono equo trattamento. La prognosi per donne e uomini ricoverati nel nostro centro è la stessa. 
Riteniamo che $\mathrm{i}$ risultati presentati in questa tesi dovrebbero essere tenuti in considerazione nella terapia dei pazienti ustionati: il trattamento attivo dovrebbe essere offerto a chiunque abbia una ragionevole possibilità di sopravvivenza, calcolata sulla base dell'età e della gravità dell'ustione. Una volta guariti da un'ustione l'aspettativa di vita è buona. Non va scordato che, tra i pazienti che muoiono in seguito ad un'ustione, le cause di morte potrebbero essere dovute a patologie di altra natura. Non si evidenziano differenze nelle mortalitá, lí dove venga offerto uguale trattamento a uomini e donne. 


\title{
ABBREVIATIONS AND ACRONYMS
}

\author{
AUC Area under the ROC curve \\ BSC Burn scoring system \\ CI Confidence interval \\ FTB Full thickness burn \\ ICD International Statistical Classification of Diseases and Related Health Problems \\ ROC Receiver operating characteristic \\ SMR Standardised mortality ratio \\ SD Standard deviation \\ TBSA \% Total body surface area burned
}




\section{LIST OF PAPERS}

This thesis is based on the following papers and manuscripts, which will be referred to in the text by their roman numerals:

I. Pompermaier L, Steinvall I, Fredrikson M, Sjöberg F: Inclusion of coexisting morbidity in a TBSA\% and age based model for the prediction of mortality after burns does not increase its predictive power. Burns 2015; 41: 1868-1876.

II. Pompermaier L, Steinvall I, Fredrikson M, Thorfinn J, Sjöberg F: Long-term survival after burns in a Swedish population. Burns 2017; 43: 157-161

III. Pompermaier L, Steinvall I, Elmasry M, Thorfinn J, Sjöberg F: Burned patients who die from causes other than the burn affect the model used to predict mortality: a national exploratory study. Burns published on line August 2017

IV. Pompermaier L, Elmasry M, M. Fredrikson, Sjöberg F, Steinvall I: Equity of burn care between the sexes in Sweden. Under submission. 


\section{INTRODUCTION}

\section{The injury}

The injury caused by the burn is the damage to skin or other tissue caused by heat, electricity, chemicals, radiation, friction, and smoke inhalation. The most common are thermal injuries caused by heat after contact with hot liquids (scalds), fire (flame burns), electricity, and hot objects (contact burns), Figure 1. (ICD codes W85-99, X00-09, X10-19, X33, reported by the National Board of Health and Welfare).

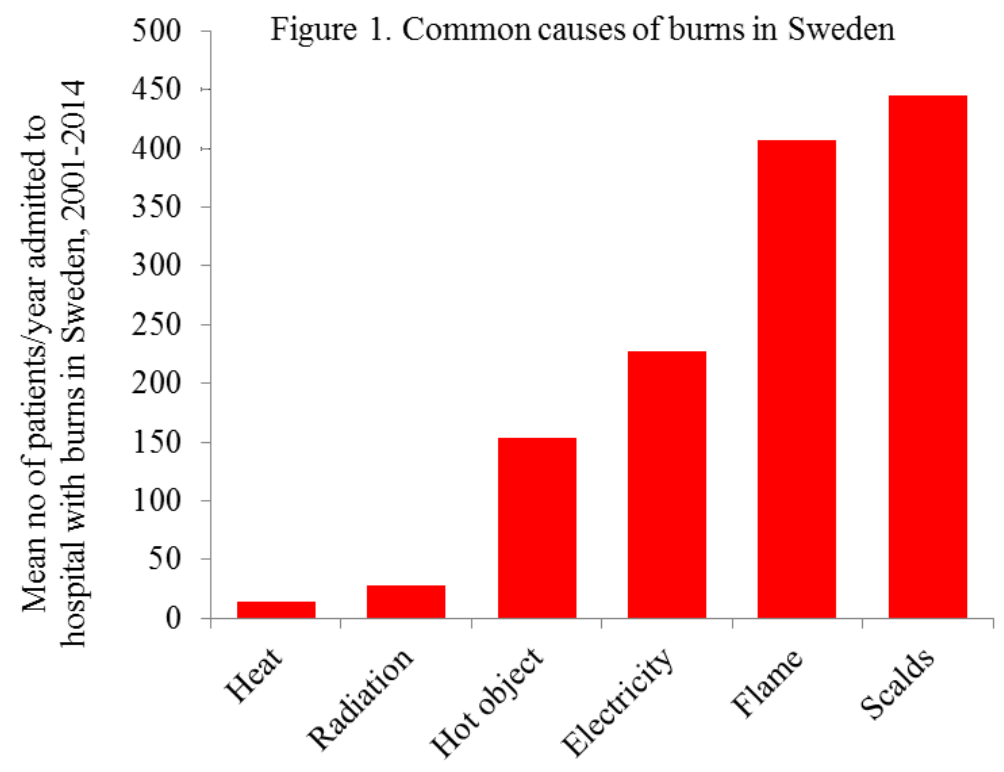

Burns can damage the structures of the skin at different depths (epidermal, dermal, or full thickness). Superficial injuries (epidermal) heal spontaneously without permanent consequences. In partial and full thickness burns (FTB) some or all layers of the skin are damaged, which leads to the risk, or development, of irreversible scars or contractures. Burns can even damage anatomical layers below the skin, such as subcutaneous fat, muscles, or bone. The unique characteristic of a burn is that it is possible to quantify the injury and its impact on the body, initiate the treatment based on this assessment, and predict the outcome. 
Both the extent of the burned area and the depth of the burn must be considered in an evaluation of the severity of the injury, and the accurate estimate of the burned skin area is essential in the initial assessment so that adequate fluid resuscitation can be provided. ${ }^{2,3}$ The extent of the burned area (TBSA \%) is estimated as the percentage of the total body surface area that is injured by dermal and full-thickness burns. Over the years many methods that differ in both accuracy and ease of use have been developed to estimate burned areas of the body. ${ }^{4-7}$ The inter-individual variability of the size and shape of bodies (as in obese patients) is still obvious, and methods developed to measure other than standard-sized bodies must be considered. $^{8,9}$

\section{Epidemiology}

A burn can affect young, healthy, people, and will have a severe impact on many of them. ${ }^{10,11}$ It can cause changes in the perception of their own body images, ${ }^{12,}{ }^{13}$ lead to temporary or chronic effects on health, ${ }^{14}$ and have serious socioeconomic effects. ${ }^{15}$ Most burns are accidental. In children scalds that occur at home are most common. Work-related flame burns are prevalent among adult men, while scalds and contact burns are the most common causes among adult women. ${ }^{16} 17,18$ However, these differences between sexes in the mechanism of injury are apparent only among adults. ${ }^{10,11,19}$ Even among elderly patients burns are most common in the home, particularly in the kitchen: flame burns predominate, followed by scalds and contact burns. ${ }^{20,21}$

In Sweden, a mean (SD) of 1556 (107) patients were admitted each year between 2001- 2014 for burns (Table I); children under 10 years were the largest group and scalds were the cause of injury in $67 \%$ of cases. ${ }^{1}$

The incidence and severity of burns, the duration of stay in hospital, and the mortality after burns are all decreasing, particularly in countries where high to middle incomes predominate, while the scarcity of data from the poorer countries makes it difficult to provide a complete overview of global trends. ${ }^{22}$ The World Health Organization has recently estimated that most of the 265000 annual deaths from burns occur in poorer countries. ${ }^{23}$ However, the in-hospital mortality after burns in the richer countries has decreased dramatically, ${ }^{24,25}$ and there are many reasons for this improved survival including, for example, the advances in intensive care (fluid resuscitation, nutritional support, and treatment with antibiotics) as well as the introduction of early excision of burn wounds. ${ }^{26-30}$ 
In Europe, the in-hospital crude mortality varies between $1.4 \%$ and $18 \%$, and is mainly dependent on differences in case-mix (TBSA\%). ${ }^{10}$ In Sweden, a mean (SD) of 87 (21) people died annually during 2001-2014 (Table 1) and the mortality has decreased from 1.3/100 000 inhabitants during the year 2001 to 0.7 in $2014, \mathrm{p}=0.004$ (Figure 2). ${ }^{1,31}$ 
Table 1: Admissions and deaths for burns in Sweden by age groups, 2001-2014

\begin{tabular}{lll}
\hline Age groups (years) & Admissions & Deaths \\
\hline $0-9$ & $351(27)$ & $2(2)$ \\
$10-19$ & $145(29)$ & $2(2)$ \\
$20-59$ & $719(54)$ & $30(8)$ \\
60 and over & $341(31)$ & $53(10)$
\end{tabular}

Data are mean (SD) by year. Data source: ICD codes W85-99, X00-09, X10-19, X33 reported by The National Board of Health and Welfare

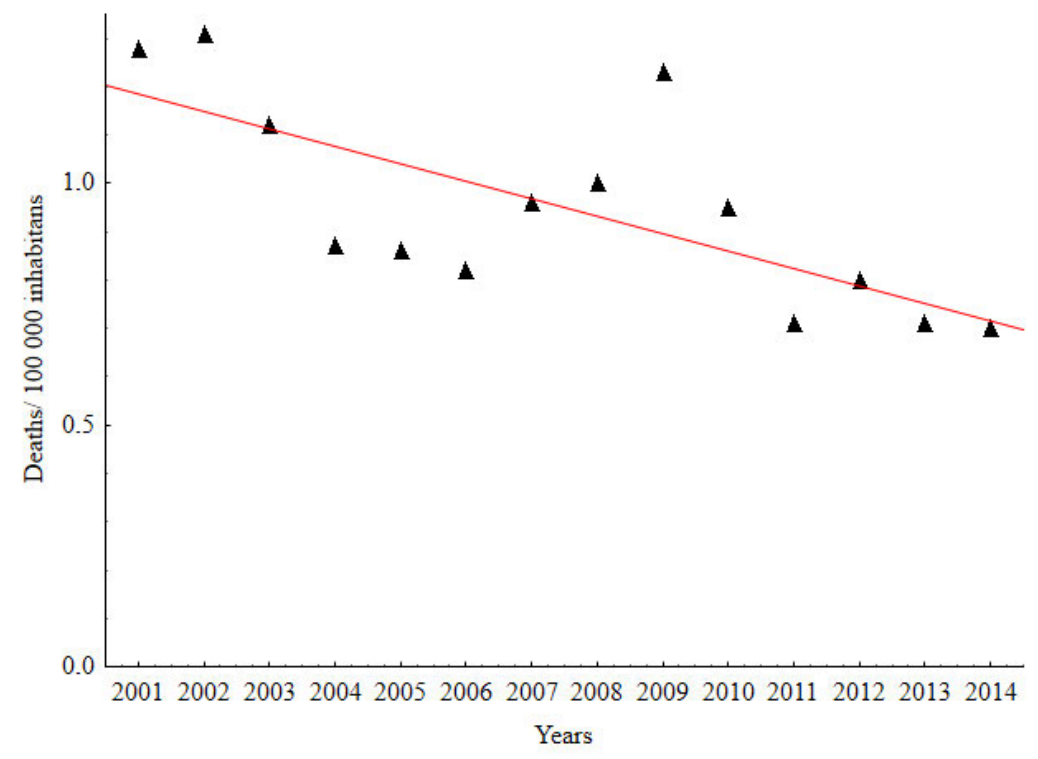

Figure 2. The incidence of deaths caused by burns in Sweden was calculated by 100000 person years. The decrease was $0.04 / 100000$ person years by year during the period 20012014, p = 0.004. Data source: ICD codes W85-99, X00-09, X10-19, X33 reported by the National Board of Health and Welfare. ${ }^{1,31}$ 


\section{Outcome measures in burn care from the perspective of mortality}

Patients with burns have heterogeneous demographic characteristics in that they include both sexes in every age range, with diverse social and medical backgrounds, but they are homogeneous as to the cause of injury, the burn. ${ }^{32,33}$ The time of injury is known, the estimate of the damage (expressed as TBSA\%) is measurable, and it is a strong indicator of the severity of the illness. ${ }^{5}$ The medical care is relatively standardised and allows daily monitoring of medical interventions and the nursing care given. ${ }^{27}$ For these reasons patients with burns provide an excellent model which is suitable for the study of differences in the delivery of treatment and its outcomes.

Outcomes can be studied by analysis of patients' characteristics (age, sex, and state of health before the burn), burn-related factors (size and depth, and presence of inhalation injuries), and the treatment given. ${ }^{34,35}$

One of the most measured outcomes is the duration of stay in hospital. ${ }^{36}$ The size of the burn and the patient's age influence the duration of admission, and their effects change during the stay in hospital. TBSA\% has an important impact on the probability of discharge early during the stay, whereas its effect declines across time, together with the progressive healing of the burns. Age, however, has a small initial effect on the discharge decision, whereas this effect increases with the time, with younger patients being discharged earlier than the older ones. ${ }^{37}$ Individual characteristics (age and ethnicity), burn-related aspects (site of the burn on the body, its depth, and its cause), and medical treatment (surgery or splinting, or both) are the factors that contribute to the development of contractures. Although they are outcomes that can impair the quality of life and limit daily activities, scars after burns have not been adequately studied. ${ }^{38}$

However, in-hospital mortality is the ultimate outcome in burn care, and it is the main theme of this thesis. Survival is of vital importance, and it remains the endpoint in daily clinical practice to avoid deaths from treatable conditions and to improve the quality of care. ${ }^{29}$

In particular we analyse the outcome "mortality" from different points of view, and try to answer questions of clinical interest that have come up during our work at the Burn Centre. 


\section{Prediction of in-hospital mortality}

Risk adjustment is an essential component of prediction models of mortality, and for more than half a century it has been calculated from the patient's age and the size of the burn. ${ }^{39}$ In 1961 Serge Baux described a simple and reliable model, the Baux score, which is the sum of age and TBSA \%. In his original thesis the point of futility (the Baux score at which the predicted mortality approached 100\%) was 100, which reflected the standard of burn care at that time. The point of futility has been adjusted upwards since then. ${ }^{40,41}$ It is important to emphasise that all prediction models have been developed on historical data, and so should not be considered as decision tools but as instruments with which to calculate and compare outcomes.

During the past few decades numerous models of mortality had been developed and different variables have been introduced. As well as age and size of burn, smoke inhalation injury has been shown to increase the risk of mortality, ${ }^{41-43}$ while the results about the effect of sex are conflicting. ${ }^{44-49}$ Clinical observations suggest that the patient's previous medical history plays an important part in the prognosis, and this has been confirmed in some large studies, but not in others. ${ }^{50,51}$

\section{Long-term survival}

In-hospital mortality has been widely studied, but what has not been sufficiently investigated is whether patients who were discharged alive have shortened long-term survival. A large proportion of patients nursed in a general intensive care unit die within the first months after discharge, ${ }^{52}$ and it has been shown that these patients have decreased survival compared with that of the general population. ${ }^{53}$ Several factors indicate that there can be differences in longterm survival of patients after burns when compared with that of patients nursed in general intensive care ${ }^{54,55}$ Patients with burns are injured, not ill; they are younger than most of those in a general intensive care unit, and their pre-existing medical conditions differ. ${ }^{51,56}$ These factors may all carry a survival advantage, which made us hypothesise that the long-term prognosis would be better for patients with burns than for those in the general intensive care unit. 


\section{Unpredictable deaths}

In-hospital mortality among patients with burns has become rare, and is usually restricted to the oldest age group or those with the most severe burns, although there are still reports of patients with mild to moderate burns who die. ${ }^{25,57,58}$

Mortality models based on age and the size of the burn are good at predicting survival after a burn (high specificity), but they are not so good at predicting deaths (low sensitivity), which is obvious among the small group of patients who die after moderate burns. ${ }^{59,60}$ Reasons other than age and the size of the burn, which are present at the time of admission or developed during the admission, seem to have a harmful effect on the outcome and must be taken in account, such as the onset of complications. ${ }^{61,62}$

\section{Medical interventions}

There is a male predominance in the incidence of burns, as often reported from high to medium income countries, and this is generally considered to result from the likelihood of exposure to hot agents or objects. ${ }^{34,45,47,63,64}$ However, risk-adjusted mortality may or may not be another difference between the sexes in burn care..$^{34,45-47,65}$

A recent Swedish study in general intensive care showed equal mortality between men and women, but a different allocation of resources for the benefit of the men. ${ }^{66}$ A female disadvantage in the level of medical care provided for general trauma and critical care patients has also been reported previously. ${ }^{67,68}$

During recent decades much attention has been addressed to the development of systems to measure the nurses' workload in a general intensive care unit. ${ }^{69-71}$ The analysis of the use of therapeutic interventions is a tool used to define the quality of care and safety of patients, and it can contribute to the development of a more efficient use of resources. ${ }^{72,}{ }^{73}$ However, scoring systems designed for general intensive care do not accurately reflect the specific interventions in burn care. In particular, management of a burn wound is a serious intervention that must be incorporated into it. ${ }^{74,} 75$ There are few systems that have been developed or modified for burn care, and none can be considered to be the standard. ${ }^{27,76,77}$ 


\section{AIMS}

The main aim of this thesis was to answer questions raised in the ward about mortality as the outcome of burn care. In particular, the following aims were addressed in the four studies:

I. To investigate the effect of adding the factor "coexisting morbidity" to a model that includes age, TBSA\%, and need for mechanical ventilation, and that predicts inhospital mortality in patients with burns.

II. To investigate the effect of the burn injury on the long-term survival in patients previously admitted for burn care.

III. To explore the data of the small group of patients who died despite having only moderate burns.

IV. To investigate potential difference in medical interventions between male and female burned patients to find out if this could have an impact on their outcome. 


\section{MATERIAL AND METHODS}

Mortality as an outcome of burn care has been studied in consecutive patients admitted to the Linköping University Hospital Burn Centre in four retrospective descriptive register studies. Burn-related data were recorded prospectively in the local database. ${ }^{27}$

\section{Data source}

\section{Linköping University Burn Centre}

The Linköping University Burn Centre was opened in 1971 and serves an area of 5 million inhabitants. ${ }^{27}$ Since 2010 it has been one of the two nationally designated burn centres in Sweden. Patients are admitted with all types of burn, including non-thermal burns (electrical, chemical, and smoke inhalation). Four of the total of seven intensive care rooms are equipped with operating room ventilation and lights to allow every procedure (excision of the burn, skin grafting, and wound care) to take place without the patient having to be transported to the main operating department. The plastic surgical ward located adjacent to the Burn Centre offers an additional four beds when necessary for patients who require wound care but not critical care.

\section{Burn Database}

Since 1993 all patients with burns admitted to the Linköping University Hospital Burn Centre have been prospectively recorded in the local burn database. ${ }^{27}$ The variables recorded are: age, sex, date of admission, type of burn (scald, contact with a hot object, friction, open flame including explosion caused by fire, electricity, chemical injury, or radiation), TBSA \%, FTB $\%$, duration of stay, need for mechanical ventilation during the first 72 hours after admission, and death from any cause during admission. ${ }^{27}$

\section{Swedish National Inpatient Register}

Since 1987 all in-patient events in public hospitals in Sweden have been recorded centrally by the Swedish National Inpatient Register. ${ }^{78}$ In case of death the cause is recorded in the Cause of Death Register. The variables that have been used in our studies are: co-existing morbidity, date of death (for calculations of duration of survival after the burn), and the cause of death (for those who died in hospital). The data are tracked by the specific Swedish Personal Identity Number, which is the date of birth combined with a social security number. ${ }^{79}$ 


\section{Burn Scoring System (BSC, Burn SCore)}

The therapeutic intervention Burn Scoring System (BSC, Burn SCore) was designed in 1992 at the Linköping Burn Centre to assess the interventions made for each patient. Since then it has been used to calculate the total cost of care for each patient. The BSC is simple to use, reliable, and has been validated against the Therapeutic Intervention Scoring System (TISS). ${ }^{27,80}$ Every patient in the Burn Centre is scored daily by the nursing staff. Depending on the amount of care and number of interventions, each of the seven scored categories bring from 0 to 4 points, except for an operation, which is calculated based on the operation time (1 hour=2 points) and the type of dressing (Figure 3). We used the data collected in this database to analyse the relation between workload and sex of the patient. 
Figure 3: Instructions for scoring of medical interventions (BSC).

\begin{tabular}{|c|c|c|c|c|}
\hline Score & 4 points & 3 points & 2 points & 1 point \\
\hline Surveillance & $\begin{array}{l}\text { As for } 3 \text { but also } \\
\text { includes : } \\
\text { continuous CVP, } \\
{ }_{\mathrm{Et}} \mathrm{CO}_{2} \text { as a result of } \\
\text { the patient's } \\
\text { condition }\end{array}$ & $\begin{array}{l}\text { Continuous } \\
\text { monitoring: ECG, } \\
\mathrm{HR}, \mathrm{S}_{\mathrm{a}} \mathrm{O}_{2}, \mathrm{MAP} \text {. } \\
\text { Every hour: urine } \\
\text { output, temperature } \\
\text { or metabolic } \\
\text { monitoring }\end{array}$ & $\begin{array}{l}\text { Continuous } \\
\text { surveillance } \\
\text { because of : } \\
\text { confusion, or } \\
\text { suicide risk, or in } \\
\text { the case of a child }\end{array}$ & $\begin{array}{l}\text { Daily control (x2): } \\
\text { temperature., fluids, } \\
\text { urine output, and } \\
\text { energy intake }\end{array}$ \\
\hline Ventilation & $\begin{array}{l}\text { Complicated } \\
\text { ventilator treatment } \\
\text { (settings changed > } \\
\text { four times/ } 24 \\
\text { hours), Weaning } \\
\text { from ventilator }\end{array}$ & $\begin{array}{l}\text { Uncomplicated } \\
\text { ventilator treatment } \\
\text { (settings changed < } \\
\text { five times / } 24 \\
\text { hours) }\end{array}$ & $\begin{array}{l}\text { Postoperative } \\
\text { spontaneous } \\
\text { breathing, oxygen } \\
\text { support, } \\
\text { physiotherapy, } \\
\text { inhalation of drugs }\end{array}$ & $\begin{array}{l}\text { Postoperative } \\
\text { surveillance }\end{array}$ \\
\hline Circulation & $\begin{array}{l}\text { Circulatory failure } \\
>1 \text { vasoactive drug }\end{array}$ & $\begin{array}{l}\text { Circulatory failure - } \\
1 \text { vasoactive drug }\end{array}$ & $\begin{array}{l}\text { Inotropic support } \\
\text { within } 48 \text { hours. } \\
\text { Risk for circulatory } \\
\text { failure, bleeding or } \\
\text { arrhythmias }\end{array}$ & $\begin{array}{l}\text { Surveillance- no } \\
\text { treatment }\end{array}$ \\
\hline Wound care & $\begin{array}{l}\text { Revision of wound } \\
\text { under general } \\
\text { anaesthesia }\end{array}$ & $\begin{array}{l}\text { Revision of wound } \\
\text { (>1 hour) under } \\
\text { nurse- given } \\
\text { analgesia or PCA }\end{array}$ & $\begin{array}{l}\text { Revision of wound } \\
(<1 \text { hour) under } \\
\text { nurse-given } \\
\text { analgesia or PCA }\end{array}$ & $\begin{array}{l}\text { Minor change of } \\
\text { dressing }\end{array}$ \\
\hline Mobilisation & $\begin{array}{l}\text { Patient care/ } \\
\text { physiotherapy } \\
\text { requiring } 5 \text { people }\end{array}$ & $\begin{array}{l}\text { Patient care/ } \\
\text { physiotherapy } \\
\text { requiring 3-4 } \\
\text { people }\end{array}$ & $\begin{array}{l}\text { Patient care/ } \\
\text { physiotherapy } \\
\text { requiring } 2 \text { persons. } \\
\text { Training activities } \\
\text { of daily life. } \\
\text { Using"walk-table" }\end{array}$ & $\begin{array}{l}\text { In-patient in the } \\
\text { Burn unit }\end{array}$ \\
\hline Clinical chemistry & $\begin{array}{l}>20 \text { blood samples/ } \\
24 \text { hours (including } \\
\text { cultures) }\end{array}$ & $\begin{array}{l}\text { 10-20 blood } \\
\text { samples/ } 24 \text { hours } \\
\text { (including cultures) }\end{array}$ & $\begin{array}{l}1-10 \text { blood samples/ } \\
24 \text { h, emergency } \\
\text { priority (<1 hour) }\end{array}$ & $\begin{array}{l}1-10 \text { blood samples/ } \\
24 \text { hours, non- } \\
\text { emergency priority } \\
\text { ( }<1 \text { hour) }\end{array}$ \\
\hline Infusion/ injections & $\begin{array}{l}\text { First and second } \\
\text { day fluid } \\
\text { resuscitation after a } \\
\text { major burn (>40\% } \\
\text { TBSA) }\end{array}$ & $\begin{array}{l}\text { Normal total } \\
\text { parenteral nutrition, } \\
2 \text { antibiotics, 1-3. } \\
\text { drugs given } \\
\text { intravenously }\end{array}$ & $\begin{array}{l}\text { Central venous line, } \\
\text { peripheral } \\
\text { intravenous line for } \\
1-2 \text { antibiotics or } \\
\text { PCA device }\end{array}$ & $\begin{array}{l}\text { Peripheral } \\
\text { intravenous line for } \\
1 \text { antibiotic, or } \\
\text { thrombosis } \\
\text { prophylaxis } \\
\text { (subcutaneous or } \\
\text { intramuscular. } \\
\text { Injection) }\end{array}$ \\
\hline
\end{tabular}

$\mathrm{CVP}=$ central venous pressure, ${ }_{\mathrm{Et}} \mathrm{CO}_{2}=$ end tidal carbon dioxide tension, $\mathrm{ECG}=$ electrocardiogram, $\mathrm{HR}=\mathrm{heart}$ rate, $\mathrm{S}_{\mathrm{a}} \mathrm{O}_{2}=$ arterial oxygen saturation, $\mathrm{MAP}=$ mean arterial pressure, $\mathrm{PCA}=$ patient controlled analgesia. 


\section{Groups studied}

All the patients were admitted with new burns (thermal, electrical, or chemical) to Linköping University Hospital Burn Centre and were recorded prospectively in the local Burn Unit Database. No age limits were applied within the groups, and patients of both sexes were included. Admissions for skin diseases were excluded (Table 2).

Table 2. Patient populations for studies I-IV.

\begin{tabular}{|c|c|c|c|}
\hline Study & $\begin{array}{l}\text { Periods during which data } \\
\text { were collected (years) }\end{array}$ & $\begin{array}{l}\text { No of } \\
\text { patients }\end{array}$ & Inclusion criteria \\
\hline I & $1997-2008$ & 772 & Admitted for burns \\
\hline II & 1993-2012 & 1487 & Discharged alive after burn care \\
\hline III & $1993-2015$ & 23 & $\begin{array}{l}\text { In-hospital deaths with Baux scores } \\
<100\end{array}$ \\
\hline IV & $2000-2015$ & 1363 & Admitted for burns \\
\hline
\end{tabular}

\section{Variables}

The main variables that were analysed are shown in Table 3.

In Paper I we defined as "pre-existing medical conditions" any of the 17 diseases enumerated in the model by Charlson in the new version validated for the ICD-10 diagnoses. ${ }^{81,82}$ Psychiatric disorders and substance misuse are not incorporated among the original conditions of the model by Charlson, but are often reported among patients with burns. ${ }^{83}$ We therefore included even those ICD-9 and ICD-10 codes, which indicated mental illness, drug misuse, or pre-existing medical conditions, either directly or indirectly. 
Table 3. Main variables studied

\begin{tabular}{|c|c|c|c|c|}
\hline Variables & Paper I & Paper II & Paper III & Paper IV \\
\hline Age (years) & $\sqrt{ }$ & $\sqrt{ }$ & $\sqrt{ }$ & $\sqrt{ }$ \\
\hline Sex & $\sqrt{ }$ & $\sqrt{ }$ & $\sqrt{ }$ & $\sqrt{ }$ \\
\hline TBSA $\%$ & $\sqrt{ }$ & $\sqrt{ }$ & $\sqrt{ }$ & $\sqrt{ }$ \\
\hline FTB & $\sqrt{ }$ & $\sqrt{ }$ & $\sqrt{ }$ & \\
\hline Cause of burn & & & $\sqrt{ }$ & \\
\hline Pre-existing medical conditions & $\sqrt{ }$ & & $\sqrt{ }$ & \\
\hline Need for mechanical ventilation & $\sqrt{ }$ & $\sqrt{ }$ & & $\sqrt{ }$ \\
\hline Duration of stay at the hospital (days) & & $\sqrt{ }$ & $\sqrt{ }$ & $\sqrt{ }$ \\
\hline In-hospital mortality & $\sqrt{ }$ & & $\sqrt{ }$ & $\sqrt{ }$ \\
\hline Causes of death & & & $\sqrt{ }$ & \\
\hline Mortality after discharge & & $\sqrt{ }$ & & \\
\hline Scoring of medical intervention (BSC) & & & & $\sqrt{ }$ \\
\hline
\end{tabular}

\section{Statistical analyses}

Data are presented as number (\%), mean (SD) or (95\% CI), or median (10th -90th centile). Normal distribution of the data (tested by the Lilliefors test for normality) could not be assumed. All statistical tests were two-tailed. Probabilities of less than 0.05 were accepted as significant.

Differences between-groups were tested for significance using non-parametric tests: for continuous variables we used the Mann-Whitney U test (paper I-IV), and for categorical variables we used Fisher's exact test (paper I) or the chi square test, as appropriate (paper IIIV). 
In paper I, the calibration of the models was tested with the Hosmer-Lemeshow goodnessof-fit statistic, and predictive values of models were analysed with the area under the receiver operating characteristic (ROC) curve (AUC). Perfect tests give an AUC of 1.0, AUC greater than 0.9 is extremely accurate, while $0.7-0.9$ indicates moderate accuracy, 0.5-0.7 little accuracy, and 0.5 none. ${ }^{84}$ The accuracy of the models were compared by calculating the deviance between their log likelihood (LL), using the chi square distribution. Mortality analysis was made with logistic regression.

In paper II survival was analysed with Cox's regression.

In paper III observed numbers of deaths were divided by the expected number of deaths to obtain the standardised mortality ratio (SMR). Mortality at our centre was then compared with mortality at other centres, and the significance of the difference in SMR was assessed by calculation of $95 \% \mathrm{CI}$ for a Poisson distribution. The AUC of the Baux prediction model, its sensitivity and specificity, and its positive and negative predictive values, were calculated using the study data.

In paper IV the effect of sex on medical interventions was tested with a linear multivariate regression.

Data were analysed with the help of Statistica (v.10, StatSoft Inc., USA) or STATA (STATA v.12.0, Stata Corporation LP College Station, TX, USA). 


\section{RESULTS}

\section{Effect of coexisting morbidity on in-hospital mortality (paper I)}

The study group $(n=772)$ was assessed for the impact of their pre-existing medical conditions on outcome (Table 4). Eighty-five percent of the patients who survived (620/725) did not have medical disorders recorded before the burn. Patients who died (47/772) were more likely to have had one or more co-existing condition than patients who survived $(p<0.05)$. The presence of pre-existing medical disorders among patients younger than 60 years was limited to one condition, except for two patients with two conditions in the 40-49 age group, and one patient with four conditions in the 50-59 years group. Patients more than 60 years old often had one to two disorders, whereas the presence of more than two disorders was a rarity even among the oldest (Table 4). Charlson's conditions ${ }^{81}$ that were associated with mortality in the study group were: myocardial infarction, congestive heart failure, cerebrovascular diseases, dementia, diabetes, renal disease or ulcers, and cancer (Table 5). Among the psychiatric disorders only severe psychiatric conditions were associated with a poor prognosis.

We have confirmed that the model described by Galeiras et al. ${ }^{42}$ gave a strong predictive value with an AUC of 0.980 (95\% CI 0.969 to 0.991). Adding the variable "co-existing medical conditions" to the model of Galeiras et al. did not improve the prediction of mortality significantly among the patients from our Burn Centre. (Table 6, Figure 4). 
Table 4. Presence of coexisting morbidity in different age groups, in relation to the survival status. Data are number or number (\%).

\begin{tabular}{|c|c|c|c|c|c|c|c|c|c|}
\hline \multirow[t]{2}{*}{ Age (years) } & \multirow{2}{*}{$\begin{array}{l}\text { No of } \\
\text { patients }\end{array}$} & \multicolumn{2}{|c|}{ Patients with comorbidity } & \multicolumn{6}{|c|}{ Charlson's conditions: } \\
\hline & & Survivors & Deaths & 1 & 2 & 3 & 4 & 5 & 6 \\
\hline $0-9$ & 175 & $12(7)$ & 0 & 12 & 0 & 0 & 0 & 0 & 0 \\
\hline $10-19$ & 93 & $6(6)$ & 0 & 6 & 0 & 0 & 0 & 0 & 0 \\
\hline $20-29$ & 82 & $3(4)$ & 0 & 3 & 0 & 0 & 0 & 0 & 0 \\
\hline $30-39$ & 85 & $4(5)$ & 0 & 4 & 0 & 0 & 0 & 0 & 0 \\
\hline $40-49$ & 89 & $14(17)$ & $2(29)$ & 14 & 2 & 0 & 0 & 0 & 0 \\
\hline $50-59$ & 94 & $12(13)$ & $4(80)$ & 15 & 0 & 0 & 1 & 0 & 0 \\
\hline $60-69$ & 62 & $25(44)$ & $2(40)$ & 14 & 8 & 4 & 1 & 0 & 0 \\
\hline $70-79$ & 45 & $14(44)$ & $9(69)$ & 13 & 4 & 3 & 2 & 1 & 0 \\
\hline $80-89$ & 34 & $10(48)$ & $9(69)$ & 8 & 7 & 1 & 1 & 1 & 1 \\
\hline$\geq 90$ & 13 & $5(50)$ & $2(67)$ & 3 & 3 & 1 & 0 & 0 & 0 \\
\hline All & 772 & $105(14)$ & $28(60)$ & 92 & 24 & 9 & 5 & 2 & 1 \\
\hline
\end{tabular}


Table 5. Presence of different coexisting conditions in relation to survival.

\begin{tabular}{|c|c|c|c|c|}
\hline Coexisting conditions & Total & $\begin{array}{l}\text { Patients who } \\
\text { survived }\end{array}$ & $\begin{array}{l}\text { Patients } \\
\text { who died }\end{array}$ & $\mathrm{p}$ value \\
\hline Myocardial infarction & $22(2.8)$ & $16(2.2)$ & $6(12.8)$ & $<0.001$ \\
\hline Congestive heart failure & $14(1.8)$ & $9(1.2)$ & $5(10.6)$ & $<0.001$ \\
\hline Peripheral vascular disease & $7(0.9)$ & $7(1.0)$ & $0(0.0)$ & 0.50 \\
\hline Cerebrovascular disease & $32(4.1)$ & $23(3.2)$ & $9(19.1)$ & $<0.001$ \\
\hline Dementia & $4(0.5)$ & $1(0.1)$ & $3(6.4)$ & $<0.001$ \\
\hline Chronic pulmonary disease & $25(3.2)$ & $23(3.2)$ & $2(4.3)$ & 0.68 \\
\hline Connective tissue disease & $8(1.0)$ & $7(1.0)$ & $1(2.1)$ & 0.45 \\
\hline Ulcer disease & $8(1.0)$ & $5(0.7)$ & $3(6.4)$ & $<0.001$ \\
\hline Mild liver disease & $11(1.4)$ & $9(1.2)$ & $2(4.3)$ & 0.09 \\
\hline Diabetes & $27(3.5)$ & $21(2.9)$ & $6(12.8)$ & $<0.001$ \\
\hline Diabetes with end organ damage & $6(0.8)$ & $4(0.6)$ & $2(4.3)$ & 0.01 \\
\hline Hemiplegia or paraplegia & $6(0.8)$ & $6(0.8)$ & $0(0.0)$ & 0.53 \\
\hline Moderate to severe renal disease & $10(1.3)$ & $5(0.7)$ & $5(10.6)$ & $<0.001$ \\
\hline Cancer & $19(2.5)$ & $12(1.7)$ & $7(14.9)$ & $<0.001$ \\
\hline Moderate to severe liver disease & $3(0.4)$ & $2(0.3)$ & $1(2.1)$ & 0.05 \\
\hline Metastatic solid tumour & $1(0.1)$ & $0(0.0)$ & $1(2.1)$ & $<0.001$ \\
\hline HIV / AIDS & 0 & 0 & 0 & - \\
\hline Severe psychiatric diseases & $66(8.5)$ & $56(7.7)$ & $10(21.3)$ & 0.001 \\
\hline Mild psychiatric diseases & $71(9.2)$ & $67(9.2)$ & $4(8.5)$ & 0.87 \\
\hline Alcohol abuse & $69(8.9)$ & $60(8.3)$ & $9(19.1)$ & 0.01 \\
\hline Drug abuse & $23(3.0)$ & $19(2.6)$ & $4(8.5)$ & 0.02 \\
\hline Total & 772 & $725(94)$ & $47(6)$ & \\
\hline
\end{tabular}

Data are number (\%).The $\mathrm{p}$ value denotes differences between survivors and non survivors. 
Table 6. Comparison of models that predict mortality with that described by Galeiras et al.

\begin{tabular}{|c|c|c|c|c|}
\hline Models & AUC & SE & $95 \% \mathrm{CI}$ & $\mathrm{p}$ value \\
\hline Galeiras $^{\mathrm{a}}$ & 0.980 & 0.006 & 0.969 to 0.991 & \\
\hline Charlson Index ${ }^{b}$ & 0.735 & 0.038 & 0.660 to 0.810 & $<0.001$ \\
\hline Galeiras+ Charlson Index ${ }^{c}$ & 0.982 & 0.005 & 0.971 to 0.992 & 1.000 \\
\hline Psychiatric disorder or misuse of alcohol or drugs ${ }^{d}$ & 0.580 & 0.038 & 0.506 to 0.654 & $<0.001$ \\
\hline $\begin{array}{l}\text { Charlson Index }+ \text { Psychiatric disorder including } \\
\text { substance misuse }\end{array}$ & 0.779 & 0.038 & 0.704 to 0.854 & $<0.001$ \\
\hline Combined model ${ }^{\mathrm{f}}$ & 0.986 & 0.005 & 0.976 to 0.995 & 1.000 \\
\hline
\end{tabular}

AUC was calculated for the following models and combinations:

${ }^{a}$ the variables of the model by Galeiras et al.= age, TBSA\%, FTB\%, sex, mechanical ventilation;

${ }^{\mathrm{b}}$ the Charlson Index only;

${ }^{c}$ a combination of the variables of the model by Galeiras et al. and Charlson Index;

d psychiatric disorders or misuse of alcohol or drugs only;

e a combination of Charlson Index and psychiatric disorders or misuse of alcohol or drugs;

f a combination of the variables of the model by Galeiras et al., the Charlson Index, and psychiatric disorders or misuse of alcohol or drugs.

The models were then compared with the model by Galeiras et al., p values are adjusted with Bonferroni correction. 


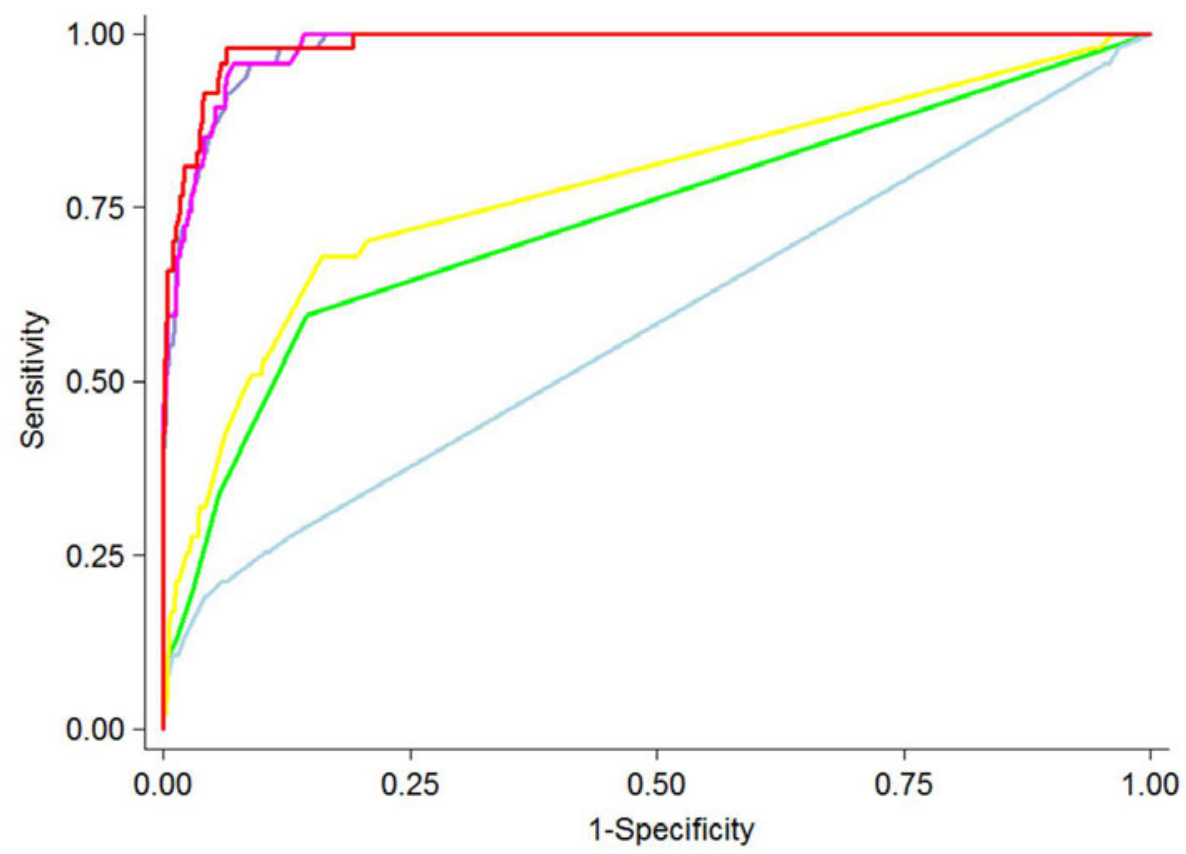

- The model by Galeiras et al. (AUC $=0.980)$

Charlson index incorporated into the model by Galeiras et al. (AUC $=0.982$ )

- Charlson index (AUC = 0.735)

- Psychiatric disorders including substance misuse ( $A U C=0.580$ )

Charlson index and psychiatric disorders including substance misuse $(A U C=0.779$ )

- Combined model (AUC $=0.986)$

Figure 4. Area under ROC curves for models that predict mortality. The combined model includes Charlson's index, psychiatric disorders, substance misuse, and the model by Galeiras et al. 


\section{Effect of burns on long-term survival (paper II)}

During the period 1993-2012, 1487 patients were discharged alive from the Linköping University Hospital Burn Centre after admission for the treatment of burns. Less than $1 \%$ of the patients died within 30 days after discharge (13/1487) and most of them (1311/1487) were still alive at the end of the follow-up. Age and the presence of full thickness burns were the only factors that reduced the long-time survival $(p<0.001)$, whereas the size of the burn (TBSA \%) and requirement for mechanical ventilation during the time in hospital did not. In Figure 5, the Kaplan-Meier curve illustrates the effect on survival of age, TBSA\%, full thickness burns \% (FTB), requirement for mechanical ventilation and sex.
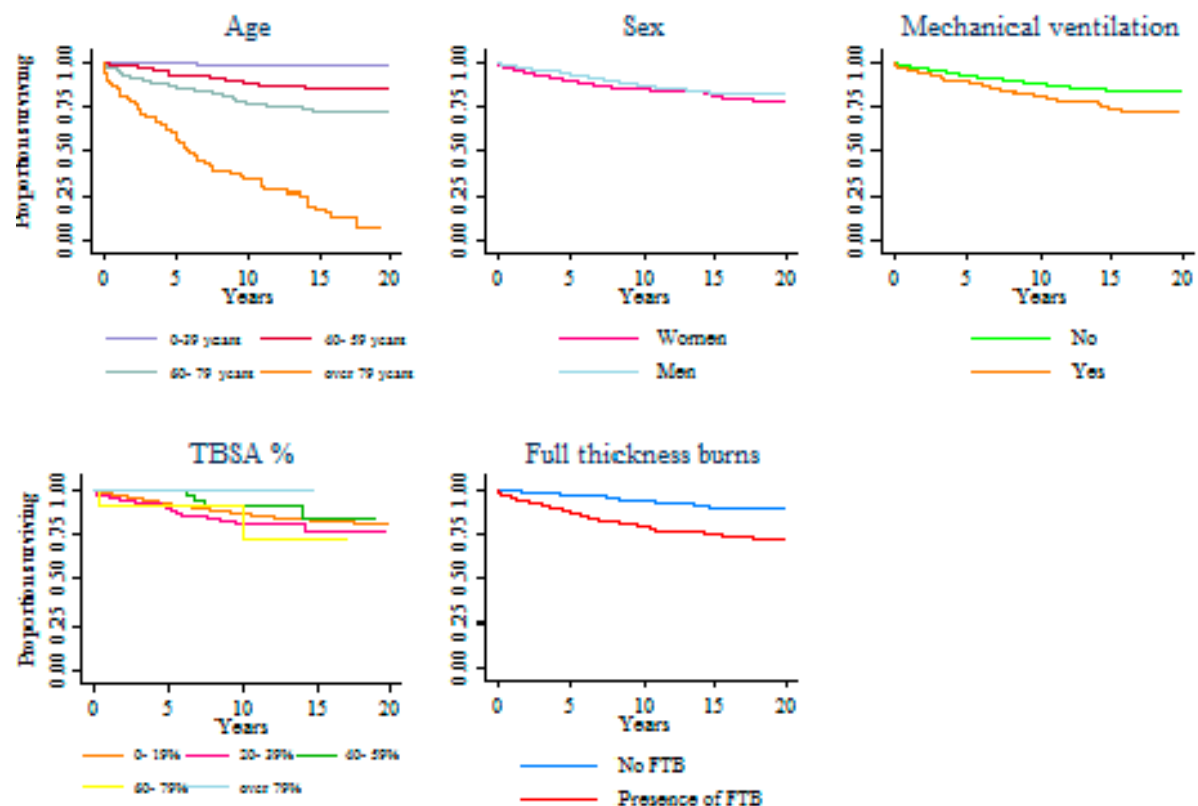

Figure 5. Kaplan-Meier plots showing long-term survival in relation to variables: age (upper left), sex (upper middle), need for mechanical ventilation during admission (upper right), TBSA\% (lower left) and presence of FTB (lower right). The proportion who survived is shown on the $\mathrm{Y}$ axis, and the years of study on the $\mathrm{X}$ axis.

Age groups: 0-39, 40-59, 60-79, and more than 79 years.

TBSA \% groups: 0-19, 20-39, 40-59, 60-79, and over 79\%. 


\section{Deaths in the group with Baux scores of less than 100 (paper III)}

Less than $5 \%$ of the patients admitted to our centre for the treatment of burns (93/1946) died during the admission and 25\% of them (23/93) had Baux scores of less than 100 (Baux scores range between 64 and 99) (Figure 6). The comparison between the patients who died and survived in the same range of the Baux score $(n=440)$, showed that those who died had larger areas of full thickness burns (median FTB $=7 \%\left(10^{\text {th }}-90^{\text {th }} 0-27\right)$ and $2 \%,(0-21.4)$, respectively, $\mathrm{p}=0.009$ ). Table 6 shows the differences between patients who died during their hospital stay with Baux scores of less than 100 compared with those who died with a Baux score of more than 100 .

Seventeen patients in the final study group (17 of $23,74 \%$ ) died for reasons not directly related to the burn (cardiovascular, cerebral, or respiratory causes) (Figure 7). The AUC calculated from the entire group $(n=1946)$ after exclusion of those 17 patients who died for reasons not directly related to the burn $(n=1929)$, improved from 0.9733 (95\% CI 0.9633 to 0.9834 ) to 0.9888 (95\% CI 0.9839 to 0.9936 ); the sensitivity increased from $45.2 \%$ till $53.9 \%$. 


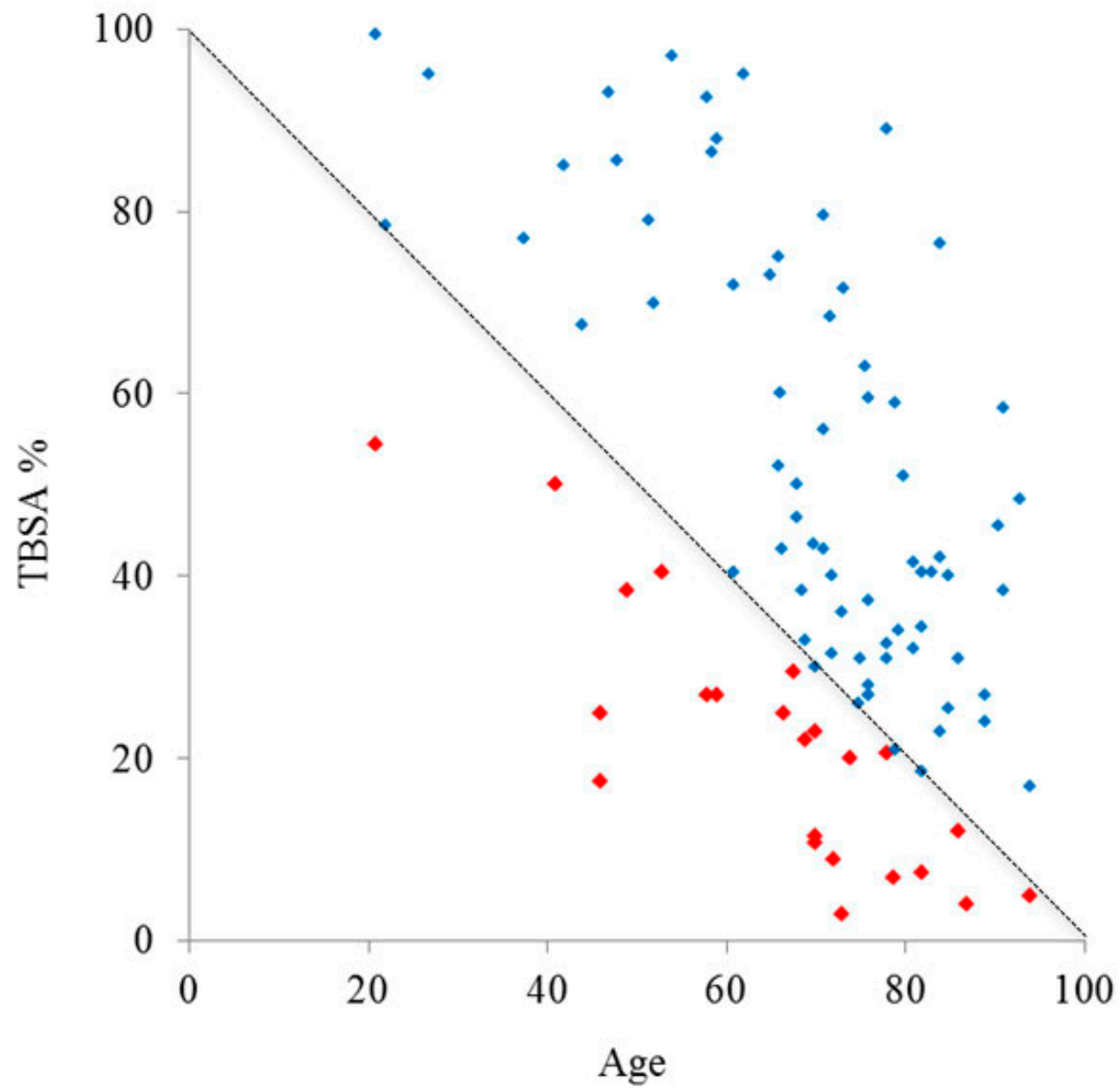

Figure 6. Age and TBSA\% among the 93 patients who died during their hospital stay, 19932015. Red diamonds $=$ deaths with a Baux score of less than 100 , and blue diamonds $=$ deaths with a Baux score of 100 or more. The dotted line indicates a Baux score of 100. 
Table 6. Details of patients who died.

\begin{tabular}{llll}
\hline & Baux score $<100$ & Baux score $\geq 100$ & P value \\
\hline Number of patients & 23 & 70 & \\
Age (years) * & $70(46-86)$ & $73(48-88)$ & 0.19 \\
TBSA\%* & $20.5(5-40.5)$ & $44.5(26.5-88.5)$ & $<0.001$ \\
FTB\%* & $7(0-27)$ & $33.5(9.3-85.3)$ & $<0.001$ \\
Duration of stay (days)* & 11 days (3-41) & 3 days $(1-52)$ & 0.009 \\
\hline
\end{tabular}

Data are number of patients, or median (10-90 centiles). Total body surface area (TBSA\%); full thickness burn (FTB\%). * Mann-Whitney U test.

Figure 7. Causes of death

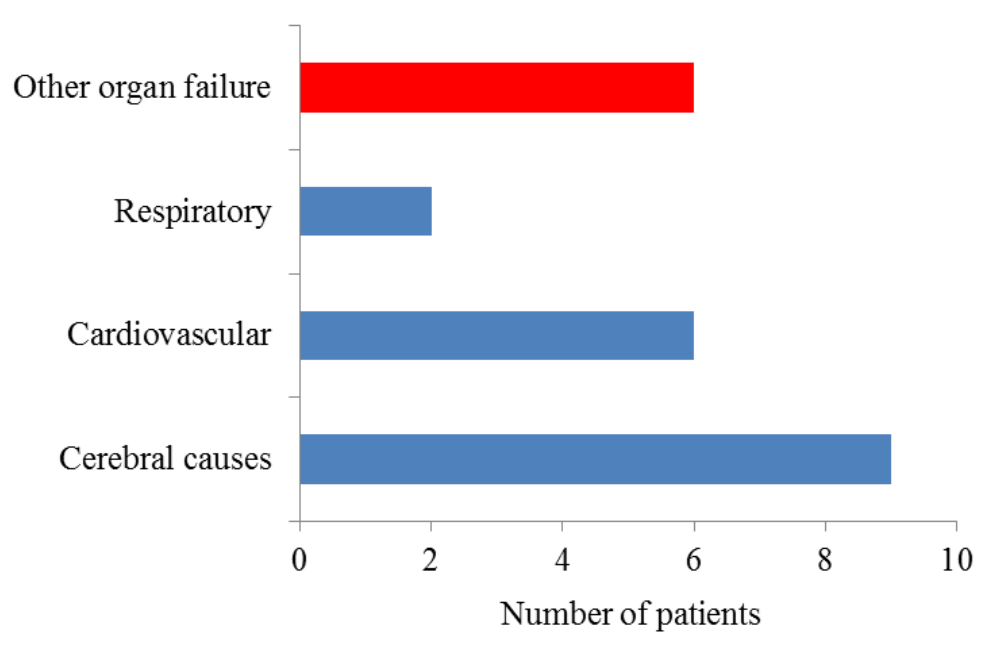




\section{Equity of burn care between the sexes in Sweden (paper IV)}

The study group included in this paper $(n=1363)$ generated a total of 22,301 recordings of

daily inpatient interventions (Table 7). The unadjusted mean difference of daily BSC recordings was higher in the male group than in the female group $(\mathrm{p}<0.001)$, but sex was not an independent factor for daily BSC points after adjustment for age, TBSA \%, and in-hospital mortality (model $\mathrm{R}^{2} 0.60, \mathrm{p}<0.001$ ) (Table 8 ).

The variation in medical interventions given to female and male patients, over different age and TBSA-groups, are illustrated in Figure 8. 
Table 7. Details of patients and intervention scores by survival status.

\begin{tabular}{|c|c|c|c|c|}
\hline & All $(n=1363)$ & $\begin{array}{l}\text { Patients who survived } \\
(\mathrm{n}=1293,95 \%)\end{array}$ & $\begin{array}{l}\text { Patients who died } \\
(\mathrm{n}=70,5 \%)\end{array}$ & $\mathrm{p}$ value \\
\hline Male sex, $\mathrm{n}(\%)^{\mathrm{a}}$ & $960(70)$ & $915(71)$ & $45(64)$ & 0.25 \\
\hline Age, years ${ }^{b}$ & $32.9(1.3-72.2)$ & $31.2(1.2-69.2)$ & $71.4(46.1-85.8)$ & $<0.001$ \\
\hline TBSA $^{\mathrm{b}}$ & $6.5(1-31)$ & $6(1-25.5)$ & $39.3(13.6-85.3)$ & $<0.001$ \\
\hline Full thickness burn $\%^{\mathrm{b}}$ & $0(0-14)$ & $0(0-9)$ & $26.1(2-71.5)$ & $<0.001$ \\
\hline \multicolumn{5}{|l|}{ BSC categories } \\
\hline Surveillance score ${ }^{\mathrm{b}}$ & $3(0-57)$ & $3(0-47)$ & $19(6-208.5)$ & $<0.001$ \\
\hline Respiration score $^{b}$ & $1(0-41)$ & $0(0-32)$ & $16.5(4.5-189)$ & $<0.001$ \\
\hline Circulation score $^{\mathrm{b}}$ & $0(0-8)$ & $0(0-3)$ & $10(0-115.5)$ & $<0.001$ \\
\hline Wound care score ${ }^{\mathrm{b}}$ & $11(1-62)$ & $11(1-60)$ & $12.5(1.5-132.5)$ & 0.11 \\
\hline Mobilization score $^{b}$ & $9(2-62)$ & $8(2-58)$ & $18(3-177)$ & $<0.001$ \\
\hline Lab tests score ${ }^{\mathrm{b}}$ & $2(0-28)$ & $1(0-24)$ & $11.5(1-88.5)$ & $<0.001$ \\
\hline Infusions score ${ }^{\mathrm{b}}$ & $3(0-61)$ & $3(0-52)$ & $18.5(4-186.5)$ & $<0.001$ \\
\hline Operation score ${ }^{b}$ & $4(0-30)$ & $4(0-25)$ & $12.5(0-82.5)$ & $<0.001$ \\
\hline Total BSC points & $34(7-348)$ & $32(7-312)$ & $133.5(22.5-1128)$ & $<0.001$ \\
\hline
\end{tabular}


Table 8. Factors associated with medical interventions on daily level: the association between sex and BSC points, adjusted for age, TBSA\%, and mortality.

\begin{tabular}{|c|c|c|c|c|}
\hline & Coefficient & SE & $\mathrm{p}$ value & $95 \% \mathrm{CI}$ \\
\hline \multicolumn{5}{|l|}{ TBSA\% } \\
\hline \multicolumn{5}{|l|}{$0-9.9$} \\
\hline $10-19.9$ & 1.89 & 0.14 & $<0.001$ & (1.62 to 2.16$)$ \\
\hline $20-29.9$ & 4.98 & 0.17 & $<0.001$ & (4.65 to 5.31$)$ \\
\hline $30-39.9$ & 6.15 & 0.20 & $<0.001$ & (5.75 to 6.55$)$ \\
\hline $40-49.9$ & 6.59 & 0.25 & $<0.001$ & (6.10 to 7.09 ) \\
\hline $50-59.9$ & 6.36 & 0.26 & $<0.001$ & (5.85 to 6.87 ) \\
\hline 60 and more & 8.06 & 0.28 & $<0.001$ & (7.52 to 8.60$)$ \\
\hline Sex (male) & 0.12 & 0.12 & 0.30 & $(-0.11$ to 0.34$)$ \\
\hline Mortality & 6.44 & 0.25 & $<0.001$ & (5.95 to 6.93$)$ \\
\hline \multicolumn{5}{|l|}{ Age } \\
\hline \multicolumn{5}{|l|}{$0-4.9$} \\
\hline $5-17.9$ & -0.38 & 0.23 & 0.10 & $(-0.84$ to 0.07$)$ \\
\hline $18-45.9$ & 1.21 & 0.18 & $<0.001$ & (0.87 to 1.56$)$ \\
\hline $46-65.9$ & 2.00 & 0.18 & $<0.001$ & (1.65 to 2.35$)$ \\
\hline 65 and older & 3.04 & 0.19 & $<0.001$ & (2.67 to 3.42$)$ \\
\hline Constant & 3.06 & 0.17 & $<0.001$ & (2.74 to 3.39 ) \\
\hline
\end{tabular}

Multivariable regression for panel data, model (between) $R^{2} 0.60, p<0.001$. Patients $n=1363$, days $n=22301$. 


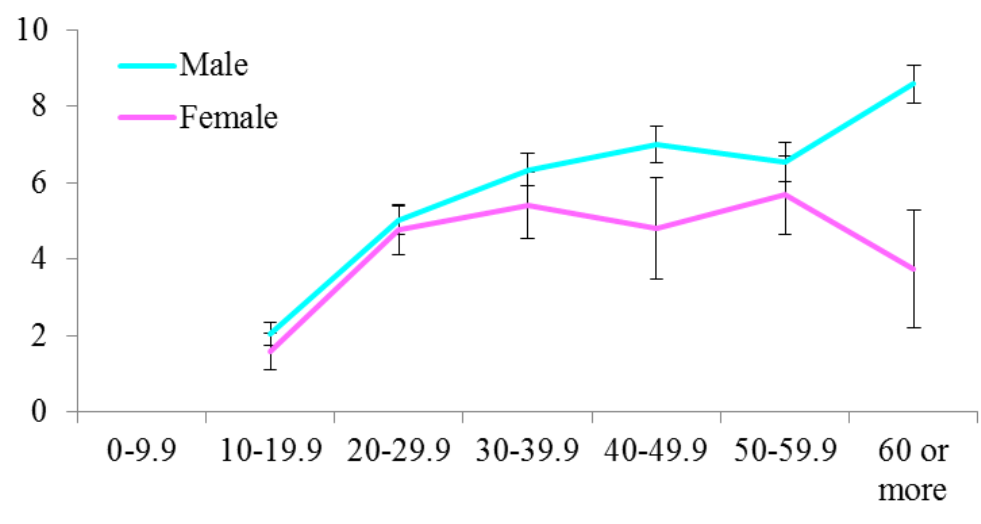

TBSA \%

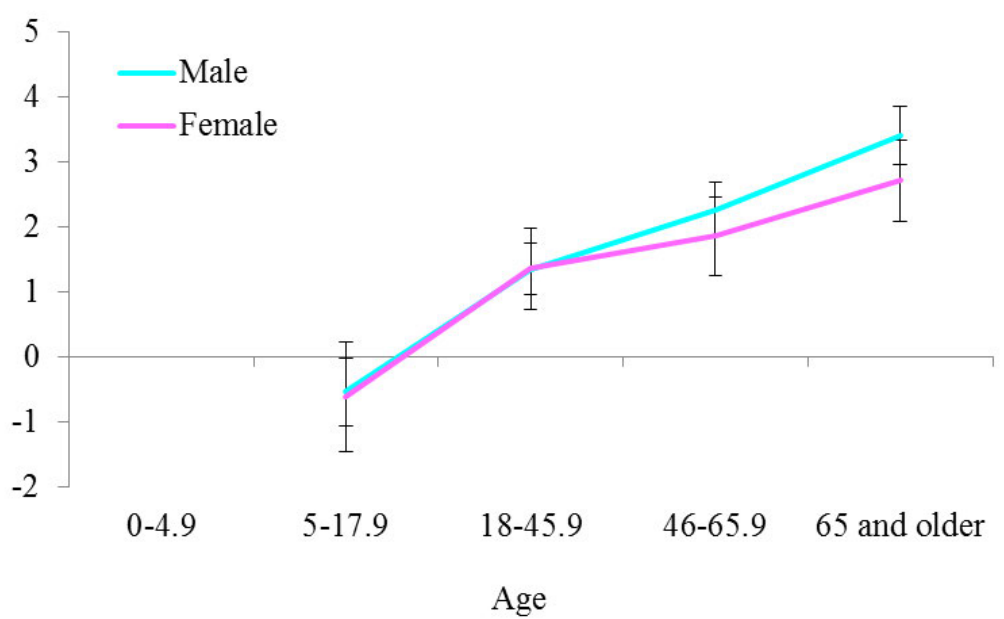

Figure 8. Variation of the medical interventions received on daily basis by TBSA\% and agegroups, among sexes. The lines are drawn by using the coefficients of the multivariable regression (Table $B$, subgroup analysis by sex). 


\section{DISCUSSION}

During burn care, many relevant questions arise every day about its outcome; some are proposed by health care workers, some by colleagues, and others by patients themselves and their relatives. Those questions usually have an answer based on experience, speculation, or logic, but evidence to support the answers has been quite limited until now. The aim of this thesis was to answer to some of the most common questions about outcome mortality that we have encountered in our daily practice.

The results presented derive from the retrospective analysis of data from patients with burns who have been admitted consecutively to the Linköping Burn Centre during the last 25 years.

\section{Prediction of in-hospital mortality}

Does the addition of coexisting morbidity to a prediction model based on age and extension of a burn improve its discrimination for in-hospital mortality?

In most cases, a burn is an accident that can hit anyone, regardless of age, sex, or medical history. However, risky behaviour and other medical conditions are over-represented among patients with burns, and include misuse of drug or alcohol, smoking, or mental disorders. ${ }^{85,86}$

As expected, many studies have shown that the older the patient, the more likely they are to have other illnesses, ${ }^{51,56}$ but analyses of the impact of pre-existing conditions on the risk of mortality have given contradictory results. Some authors did not find that coexisting conditions had an impact on in-hospital mortality, ${ }^{56}$ and others did not consider them to be a factor that deserved to be included in a prediction model. ${ }^{50}$

On the other hand, recent studies have shown that pre-existing disorders do have an impact on mortality, particularly among younger patients. ${ }^{87,88}$ However, severe conditions such as HIV/ AIDS, metastatic cancer, and renal and liver diseases raised the odds in favour of death, and the risk of mortality increased with the number of disorders. ${ }^{51}$

In our first study we confirmed the excellent prognostic power of a model for the prediction of mortality based on the variables age and TBSA\%, ${ }^{42}$ whereas the addition of coexisting conditions to this model did not significantly improve its predictive value.

Less than a fifth of the patients admitted to our Burn Centre had some pre-existing medical conditions. ${ }^{34}$ As expected, these were more common among older patients, independent of 
their sex, and psychiatric diagnoses, and misuse of alcohol (and other substances) was overrepresented throughout.

This result suggests that presence of pre-existing morbidity does not worsen the prognosis any more than age and the extension of the burn (TBSA \%) do. A further deduction is that the factor "age" already adjusts for coexisting conditions, in that none of the patients in the youngest groups ( 0 to 39 years old) had a severe pre-existing disorder, and there were no deaths in this group. ${ }^{34}$ This made it difficult, however, to evaluate the impact of pre-existing disorders (however serious) on the mortality among younger patients. Our conclusions therefore need to be interpreted with caution.

\section{Long-term survival}

Do the effects of the burn continue to be a threat to survival even after discharge?

The 30-day mortality among injured patients in intensive care units is strongly related to age (> 50 years), severe head injuries, and serious illness on admission. Injured patients compared with a general control group, also have increased mortality until 3.5 years after discharge. ${ }^{89}$ Often, the leading cause of death after discharge is related to the injury, and important risk factors are age, a long stay in hospital, and unintentional falls. ${ }^{90,}{ }^{91}$ However, the one-year prognosis for patients treated in surgical intensive care units for more than 30 days is better, and the figure of $62 \%(60 / 136)$ has been reported. ${ }^{92}$ Not surprisingly, surviving a serious injury in old age does not guarantee a long life after discharge, particularly among the oldest patients with pre-existing diseases. ${ }^{93}$

Studies of long-term survival after burn care are few. Mortality after discharge is low in both children with massive burns followed up for 15 years, and in military personnel followed up for 10 years after combat-related burns (5\% and $1.3 \%$, respectively), and the few deaths are rarely related to the burn. ${ }^{94,} 95$ Although the results are interesting the low generalisability makes it doubtful whether these results can be used for predictions among people with burns generally, as the conclusions were generated by two highly-specific subgroups. ${ }^{94,95}$

In our second study we showed that the factor "age" is the one that governs survival after discharge. ${ }^{96}$ We found a significant effect of deep damage, but it was quantitatively almost negligible, whereas TBSA \% did not have an effect in the long term. 
These results suggest that the size of the injury ceases to affect survival after treatment has been completed and that, when patients survive a burn, their long-term prognosis is good. It has been even suggested that those who survive intensive care for a burn may have a survival advantage explained by a greater physiological reserve, as they are younger and have fewer coexisting conditions than the patients who died before discharge. ${ }^{97}$

Our data further support the policy that active treatment should be offered to anyone with a reasonable chance of survival, as the quality of life after burn care is good, and improves steadily during the first years after discharge. ${ }^{98}$

\section{Unpredictable deaths}

Are there common and predictable features shared by those patients who died despite moderate burns?

Young patients with small burns should not die. ${ }^{40}$ However, some do despite limited injuries, though these are rare. ${ }^{62}$ The presence of inhalation injuries can reduce survival among patients with small TBSA $^{99}$ and the development of complications worsens the outcome in this group. $^{62}$ The principal causes of death in Sweden are cardiovascular disorders and cancer ${ }^{100}$ and, among those with burns, multiple organ failure. ${ }^{101,102}$

In our third study, we showed that the causes of death in most patients who died with a low Baux score were not directly related to the burn, and therefore they cannot be predicted by models of burn-specific mortality.

During the last 23 years, 23 patients with a Baux score of less than 100 died at our Burn Centre: a quarter of all deaths. ${ }^{103}$ This group is heterogeneous in the characteristics of the burns and factors that could affect survival, and they did not differ significantly from the survivors in the same range of Baux score by demographic characteristics.

In 17 of the 23 deaths the cause was not primarily attributable to the burn (but to cerebral, cardiovascular. or respiratory failure), whereas less than a third of them died of multiorgan failure. ${ }^{103}$ Similar results have been published in a report from an Australian burn centre: almost a quarter of the patients with burns who died (9 of 24) had Baux scores of less than 
100 , and five of them died from cerebrovascular or respiratory failure, three from multiorgan failure, one from sepsis, and in one case the cause remained unknown. ${ }^{104}$

The Baux score (sum of the age and TBSA \%) still remains an excellent model to use to predict the risk of mortality in burns. ${ }^{40,41}$ It has a high specificity and easily predicts those patients who will survive the burns (younger people with small burns) whereas it cannot predict exactly which ones will die (low sensitivity). ${ }^{60}$ In fact a high Baux score indicates a high risk of death, but low scores do not guarantee survival.

The oldest patients with burns deserve special consideration. In elderly people (>65 years), the risk of death increases linearly with age, and no cut-off age has been shown to be associated with increased mortality. ${ }^{105}$ However, despite the global decrease in burn-related mortality, ${ }^{33}$ there is no sign of this trend among the elderly, for whom the LD50 burn size has remained at 25\% TBSA for the last 20 years. $^{25,48,105}$ The prognosis among elderly people seems to be worse than among younger patients, even when the TBSA\% is lower and inhalation injuries fewer. ${ }^{106}$ Improvements in survival have been reported even among elderly patients, but whether this depends on the different strategies in the management of burns (such as early excision and grafting or conservative treatment), or on the increasing proportion of smaller burns that are referred to burn centres, still needs to be clarified. ${ }^{25} 21$

Older patients seem to require more time to heal than younger, but the reasons are not entirely clear. ${ }^{107}$ It may be that caregiver's speculations about patient's ages, a long stay at hospital, and inevitable but often reversible worsening of pre-existing conditions, are sometimes reasons given to justify cessation of treatment, perhaps too early. An alternative approach is to base decisions about treatment on medical and scientific grounds, which is the line chosen at our burn centre. As well as early excision and grafting that is our standard treatment strategy, as we give the patients (particularly the older ones) more time.

The conclusion that a number of patients with burns die for reasons other than the burn itself, an exception among burned patients in general, adds further to our feeling that the prognostic models of mortality can be optimised if deaths that are not related to the burn itself are excluded from the model.

To our knowledge this assumption had never been tested, and a multicentre approach would provide us with a larger sample and improve the generalisability of our conclusions. 


\section{Medical interventions}

Are there discrepancies in treatments among sexes that could affect the outcome?

Globally, adult men are more likely to present with burns than women, ${ }^{22}$ whereas differences among children are controversial. ${ }^{16,108}{ }^{109}$ Men's health seem to be more likely to be affected by "risky" behaviour such as smoking or drinking alcohol, ${ }^{83,110,111}$ whereas women's health is influenced by more structural and psychosocial factors. ${ }^{112,113}$ However, sex discrimination in health-care expenditure with a consequent survival advantage for men is well-known in some countries, ${ }^{67,} 114$ so much so that female patients assess the quality of their hospital care significantly worse than do male patients, and call for better nursing care and better management of their pain. ${ }^{115}$ A recent Swedish study has shown that male patients with trauma were more likely than women to obtain the highest prehospital priority, and to be transported directly to a designated trauma centre, ${ }^{116}$ despite the fact that Sweden is at the forefront of promoting equity between the sexes. ${ }^{117}$ However, it is still necessary to verify whether the differing approaches between the sexes depends on objective (and hence measurable) differences in the severity of illness or on mere sexual stereotypes.

Patients with burns provide an optimal model in which to study sex-related differences in both interventions and outcomes; the cause of admission and the burn itself is the same for every patient. The time of the injury is known, the size of the burn indicates its severity and can be quantified, and the care of the burn is relatively standard. We have therefore investigated whether there is a discrepancy in the medical treatment of patients with burns according to their sex, analysed the interventions made at our Burn Centre for each patient, and scored them daily with the Burn SCoring system. ${ }^{27}$

In our fourth study we showed equality between the sexes in the allocation of resources, which is in line with the results previously recorded at our Centre about equivalent survival between sexes. ${ }^{34,47}$

This is a unique finding in this context, both as a method and in a national or international perspective. We have shown equality among sexes in delivery of therapeutic interventions and outcome, which is a pleasing conclusion that can lead to further speculation - particularly, if the difference in outcome between the sexes at other burn centres depends on the underlying severity of injury, or an unequal use of resources. This is the first time to our knowledge that treatments had been included as variables in an analysis of the outcome of burn care. 


\section{Limitations}

The first is that a single-centre investigation made in a country with a small population reduces the generalisability of our conclusions. The absence of severe pre-existing conditions, particularly in the youngest age groups, made it difficult to evaluate the whole range of issues that have an impact on mortality. However, patients with burns admitted to our centre comprise all patients with burns without exclusion for age, sex, severity of burn, or cause of injury, and some global similarities such as the decreases in the incidence of burns; the severity of injury; mortality; and the duration of stay, ${ }^{33}$ give value to our results.

Secondly, to investigate the effect of burns on long-term survival, the comparison with an adequately-matched control group would have improved the quality of the study. Matching by age and sex would not be sufficient. As misuse of substances and mental disorders are overrepresented among patients with burns, and we assume that these risk factors affect long-term survival, the control group should also be matched for these variables. However, an attempt to match too many factors can decrease the availability of similar controls. ${ }^{118}$

Thirdly, retrospective studies of registers investigate specific outcomes looking backwards at data collected about previous patients. ${ }^{119}$ Diagnostic codes reported in patients' records are based on medical case notes, and therefore depend on the accuracy of the estimation of the variables recorded. However, the accuracy of codes for the diagnosis of burns in administrative data has been validated before. ${ }^{120}$ The sources of data analysed in this thesis were the Swedish National Inpatient Register and the Burn Scoring System, and both registers have been validated. ${ }^{27,78}$

Finally, a main source of uncertainty is the recorded causes of death, which are based on the previous clinical diagnoses. It can be challenging for the clinicians to decide which conditions definitely caused the death. Necropsy could be helpful, but discrepancies between coroners $^{\prime}$ death certificates and clinical causes of death have previously been shown. ${ }^{101,121,122}$ However, necropsies are not mandatory in Sweden. ${ }^{123}$ 


\section{CONCLUSIONS}

- Factors that should be included in the prediction of risk of in-hospital mortality are age, TBSA \%, the presence of a full thickness burn, and the need for mechanical ventilation.

- Our data do not support the hypothesis that pre-existing medical conditions from a single centre improve models for the prediction of mortality.

- Less than $1 \%$ of patients die within 30 days after discharge.

- Age and full thickness burns are factors associated with reductions in long-term survival.

- Patients who died with Baux scores of $<100$ did so mainly for reasons other than the burn.

- As anticipated, the predictive value of the Baux scores improves if patients who die of causes other than the burn are excluded from the prediction model of mortality.

- We found that the delivery of medical interventions was independent of the sex of the patients. 


\section{ACKNOWLEDGEMENTS}

Many people have accompanied me during the realization of this thesis. In particular, I would like to thank:

Folke Sjöberg, my main supervisor, for having taken me to your amazing team. Thank you for having spurred me when I needed it and always inspired me. Your inexhaustible optimism encourages me to move on.

Ingrid Steinvall, co-author, teacher, mentor. Without you the way up to here would have been longer, impervious and not so enjoyable. I have learned so much from you and I hope to keep on working with you even after this thesis is completed.

Mats Fredrikson, co-author and statistical guide. You understand (and answer) my questions even when they are unclear to me!

Johan Thorfinn, co-author and sex affirming surgeon-companion. Thank for your friendly support in and outside the theater!

The head of department Thomas Hansson, and my friends and colleagues at the Department of Plastic Surgery, Hand Surgery, and Burns, for creating a stimulating place where it is really nice to work.

Zilla Everbrand and Eva Lago, who steer meticulously every detail at our clinic.

Hasse Krook, former head of the Department of General Surgery at the Vrinnevi Hospital of Norrköping and to my former surgeons' colleagues, to give me the fantastic chance to be a general surgeon, despite my plastic ambitions.

All my friends, old and new, close and far, in particular Raffaella, Ingrid, Elena, Andrea, Carolina, Malgorzata, Helena, Juan Carlos, Karolina, David, Annika, Jens, Karin, Mijo, Veronica, Christian, Linda, Per, Caroline, Jonas, Bodil, Jonas, Daniel and Moa.

The book club girls Ala, Anna, Ylva, Jenny and Johanna, for the stimulating literary discussions and the tasty dinners, and their partners who make our book evenings possible!

My Italian and Swedish families, which live at the opposite's ends of Europe, but are so similar. Thank you for your cheerfulness, constant love and support! 
My parents-in-law Marianne and Bernd Wijkman, for welcoming me warmly into your family and always finding a reason to organize magnificent parties!

My brother Simone Pompermaier, the most entertaining and wise person I know. The first I call when I'm in trouble, the only one who make me laugh to tears. I love you, fratellino!

My parents Rita and Roberto, for your never-ending love and for believing in me and encouraging me to follow my dreams, even though my dreams have led me far. Mamma, you are my inspiration! Papili, rolling stones will not make moss, but they move the mountains...

My "amore grande", Magnus Wijkman, for unconditional love and tireless support. Our diversities complete us, together everything is possible, everywhere! I still cannot believe you are mine!

My "amore piccolo", Robert, the most wonderful son a proud mother could dream of! We will conquer the world hand in hand. 


\section{REFERENCES}

1. Swedish National Board of Health and Welfare. Open access database.

http://www.socialstyrelsen.se/statistik/statistikdatabas/yttreorsakertillskadorochforgiftning ar. Accessed May 2017.

2. Parvizi, D., et al., The potential impact of wrong TBSA estimations on fluid resuscitation in patients suffering from burns: Things to keep in mind. Burns, 2014. 40(2): p. 241-245.

3. Sadideen, H., et al., Does Overestimation of Burn Size in Children Requiring Fluid Resuscitation Cause Any Harm? J Burn Care Res, 2017. 38(2): p. e546-e551.

4. Hettiaratchy, S. and R. Papini, Initial management of a major burn: II-assessment and resuscitation. BMJ: British Medical Journal, 2004. 329(7457): p. 101.

5. Giretzlehner, M., et al., The determination of total burn surface area: How much difference? Burns, 2013. 39(6): p. 1107-1113.

6. Amirsheybani, H.R., et al., The natural history of the growth of the hand: I. Hand area as a percentage of body surface area. Plast Reconstr Surg, 2001. 107(3): p. 726-33.

7. Armstrong, J.R., et al., Quantitative Analysis of Estimated Burn Size Accuracy for Transfer Patients. Journal of Burn Care \& Research, 2017. 38(1): p. e30-e35.

8. Butz, D.R., et al., Is palmar surface area a reliable tool to estimate burn surface areas in obese patients? J Burn Care Res, 2015. 36(1): p. 87-91.

9. Neaman, K.C., et al., A new method for estimation of involved BSAs for obese and normalweight patients with burn injury. J Burn Care Res, 2011. 32(3): p. 421-8.

10. Brusselaers, N., et al., Severe burn injury in Europe: a systematic review of the incidence, etiology, morbidity, and mortality. Crit Care, 2010. 14(5): p. R188.

11. Queiroz, L.F., et al., Epidemiology and outcome analysis of burn patients admitted to an Intensive Care Unit in a University Hospital. Burns, 2016. 42(3): p. 655-62.

12. Zamanzadeh, V., et al., Preserving self-concept in the burn survivors: a qualitative study. Indian J Palliat Care, 2015. 21(2): p. 182-91.

13. Druery, M., T.L.H. Brown, and M. Muller, Long term functional outcomes and quality of life following severe burn injury. Burns, 2005. 31(6): p. 692-695.

14. ter Smitten, M.H., R. de Graaf, and N.E. Van Loey, Prevalence and co-morbidity of psychiatric disorders 1-4 years after burn. Burns, 2011. 37(5): p. 753-761. 
15. Orwelius, L., et al., Long term health-related quality of life after burns is strongly dependent on pre-existing disease and psychosocial issues and less due to the burn itself. Burns, 2013. 39(2): p. 229-35.

16. Tegtmeyer, L.C., et al., Retrospective analysis on thermal injuries in children-Demographic, etiological and clinical data of German and Austrian pediatric hospitals 2006-2015Approaching the new German burn registry. Burns, 2017.

17. Seyed-Forootan, K., et al., LA50 in burn injuries. Ann Burns Fire Disasters, 2016. 29(1): p. 1417.

18. Bessey, P.Q., et al., Synopsis of the 2013 annual report of the national burn repository. J Burn Care Res, 2014. 35 Suppl 2: p. S218-34.

19. Blom, L., et al., Gender differences in burns: A study from emergency centres in the Western Cape, South Africa. Burns, 2016. 42(7): p. 1600-1608.

20. Keck, M., et al., Burn treatment in the elderly. Burns, 2009. 35(8): p. 1071-9.

21. Wearn, C., et al., Outcomes of burns in the elderly: Revised estimates from the Birmingham Burn Centre. Burns, 2015. 41(6): p. 1161-1168.

22. Smolle, C., et al., Recent trends in burn epidemiology worldwide: A systematic review. Burns, 2016.

23. World Health Organization. Burns: a global public health problem. http://www.who.int/mediacentre/factsheets/fs365/en/. Accessed February 2017.

24. Brusselaers, N., et al., Outcome and changes over time in survival following severe burns from 1985 to 2004. Intensive Care Med, 2005. 31(12): p. 1648-53.

25. Jackson, P.C., et al., Revised estimates of mortality from the Birmingham Burn Centre, 20012010: a continuing analysis over 65 years. Ann Surg, 2014. 259(5): p. 979-84.

26. Bloemsma, G.C., et al., Mortality and causes of death in a burn centre. Burns, 2008. 34(8): p. 1103-7.

27. Sjoberg, F., et al., Utility of an intervention scoring system in documenting effects of changes in burn treatment. Burns, 2000. 26(6): p. 553-9.

28. Ong, Y.S., M. Samuel, and C. Song, Meta-analysis of early excision of burns. Burns, 2006. 32(2): p. 145-50.

29. Pereira, C., K. Murphy, and D. Herndon, Outcome measures in burn care. Is mortality dead? Burns, 2004. 30(8): p. 761-71.

30. Abdelrahman, l., et al., Improvement in mortality at a National Burn Centre since 2000: Was it the result of increased resources? Medicine (Baltimore), 2017. 96(25): p. e6727. 
31. Swedish National Board of Health and Welfare. Open access database.

http://www.socialstyrelsen.se/statistik/statistikdatabas/dodsorsaker. Accessed September 2017.

32. Peck, M.D., Epidemiology of burns throughout the world. Part I: Distribution and risk factors. Burns, 2011. 37(7): p. 1087-100.

33. Smolle, C., et al., Recent trends in burn epidemiology worldwide: A systematic review. Burns, 2017. 43(2): p. 249-257.

34. Pompermaier, L., et al., Inclusion of coexisting morbidity in a TBSA\% and age based model for the prediction of mortality after burns does not increase its predictive power. Burns, 2015.

35. Israel, J.S., D.G. Greenhalgh, and A.L. Gibson, Variations in Burn Excision and Grafting: A Survey of the American Burn Association. J Burn Care Res, 2017. 38(1): p. e125-e132.

36. Hussain, A., F. Choukairi, and K. Dunn, Predicting survival in thermal injury: A systematic review of methodology of composite prediction models. Burns, 2013.

37. Taylor, S.L., et al., A competing risk analysis for hospital length of stay in patients with burns. JAMA Surg, 2015. 150(5): p. 450-6.

38. Oosterwijk, A.M., et al., Prevalence of scar contractures after burn: A systematic review. Burns, 2017. 43(1): p. 41-49.

39. Bull, J.P. and J.R. Squire, A Study of Mortality in a Burns Unit: Standards for the Evaluation of Alternative Methods of Treatment. Ann Surg, 1949. 130(2): p. 160-73.

40. Roberts, G., et al., The Baux score is dead. Long live the Baux score: A 27-year retrospective cohort study of mortality at a regional burns service. J Trauma, 2012. 72(1): p. 251-6.

41. Osler, T., L.G. Glance, and D.W. Hosmer, Simplified Estimates of the Probability of Death After Burn Injuries: Extending and Updating the Baux Score. J Trauma, 2009.

42. Galeiras, R., et al., A model for predicting mortality among critically ill burn victims. Burns, 2009. 35(2): p. 201-9.

43. Salehi, S.H., et al., Comparison of six outcome prediction models in an adult burn population in a developing country. Ann Burns Fire Disasters, 2017. 30(1): p. 13-17.

44. O'Keefe, G.E., J.L. Hunt, and G.F. Purdue, An evaluation of risk factors for mortality after burn trauma and the identification of gender-dependent differences in outcomes. J Am Coll Surg, 2001. 192(2): p. 153-60.

45. George, R.L., et al., The association between sex and mortality among burn patients as modified by age. J Burn Care Rehabil, 2005. 26(5): p. 416-21.

46. Ryan, C.M., et al., Objective estimates of the probability of death from burn injuries. N Engl J Med, 1998. 338(6): p. 362-6. 
47. Steinvall, I., et al., Mortality after thermal injury: no sex-related difference. J Trauma, 2011. 70(4): p. 959-64.

48. Pereira, C.T., et al., Age-dependent differences in survival after severe burns: a unicentric review of 1,674 patients and 179 autopsies over 15 years. J Am Coll Surg, 2006. 202(3): p. $536-48$.

49. Moore, E.C., et al., Women are more than twice as likely to die from burns as men in Australia and New Zealand: an unexpected finding of the Burns Evaluation And Mortality (BEAM) Study. J Crit Care, 2014. 29(4): p. 594-8.

50. McGwin, G., Jr., et al., Improving the ability to predict mortality among burn patients. Burns, 2008. 34(3): p. 320-7.

51. Thombs, B.D., et al., The effects of preexisting medical comorbidities on mortality and length of hospital stay in acute burn injury: evidence from a national sample of 31,338 adult patients. Ann Surg, 2007. 245(4): p. 629-34.

52. Steenbergen, S., et al., Long-term treated intensive care patients outcomes: the one-year mortality rate, quality of life, health care use and long-term complications as reported by general practitioners. BMC Anesthesiol, 2015. 15: p. 142.

53. Brinkman, S., et al., Mortality after hospital discharge in ICU patients. Crit Care Med, 2013. 41(5): p. 1229-36.

54. Williams, T.A., et al., Determinants of long-term survival after intensive care. Crit Care Med, 2008. 36(5): p. 1523-30.

55. Davidson, G.H., et al., Long-term survival of adult trauma patients. JAMA, 2011. 305(10): p. 1001-7.

56. Lundgren, R.S., et al., Influence of comorbidities and age on outcome following burn injury in older adults. J Burn Care Res, 2009. 30(2): p. 307-14.

57. Akita, S., et al., Elevated circulating leukemia inhibitory factor in patients with extensive burns. J Burn Care Res, 2006. 27(2): p. 221-5.

58. National Burn Repository 2015. Annual Report. American Burn Association. 10 February 2016]; Available from: http://www.ameriburn.org/2015NBRAnnualReport.pdf.

59. Sheppard, N.N., et al., Prognostic scoring systems in burns: a review. Burns, 2011. 37(8): p. 1288-95.

60. Steinvall, I., et al., Standardised mortality ratio based on the sum of age and percentage total body surface area burned is an adequate quality indicator in burn care: An exploratory review. Burns, 2016. 42(1): p. 28-40. 
61. Faurie, M.P., et al., A closer look at burn injuries and epilepsy in a developing world burn service. S Afr J Surg, 2015. 53(3 and 4): p. 48-50.

62. Travis, T.E., et al., Factors Impacting the Likelihood of Death in Patients with Small TBSA Burns. J Burn Care Res, 2014.

63. Engrav, L.H., et al., Harborview burns--1974 to 2009. PLoS One, 2012. 7(7): p. e40086.

64. Kerby, J.D., et al., Sex differences in mortality after burn injury: results of analysis of the National Burn Repository of the American Burn Association. J Burn Care Res, 2006. 27(4): p. 452-6.

65. Burton, K.R., et al., A population-based study of the epidemiology of acute adult burn injuries in the Calgary Health Region and factors associated with mortality and hospital length of stay from 1995 to 2004. Burns, 2009. 35(4): p. 572-9.

66. Samuelsson, C., et al., Gender differences in outcome and use of resources do exist in Swedish intensive care, but to no advantage for women of premenopausal age. Critical Care, 2015. 19(1): p. 1-9.

67. Fowler, R.A., et al., Sex-and age-based differences in the delivery and outcomes of critical care. CMAJ, 2007. 177(12): p. 1513-9.

68. Gomez, D., et al., Gender-associated differences in access to trauma center care: $A$ population-based analysis. Surgery, 2012. 152(2): p. 179-85.

69. Yamase, H., Development of a comprehensive scoring system to measure multifaceted nursing workloads in ICU. Nurs Health Sci, 2003. 5(4): p. 299-308.

70. Walther, S.M., et al., Multicentre study of validity and interrater reliability of the modified Nursing Care Recording System (NCR11) for assessment of workload in the ICU. Acta Anaesthesiol Scand, 2004. 48(6): p. 690-6.

71. Cullen, D.J., et al., Therapeutic intervention scoring system: a method for quantitative comparison of patient care. Crit Care Med, 1974. 2(2): p. 57-60.

72. Carayon, P. and A.P. Gurses, A human factors engineering conceptual framework of nursing workload and patient safety in intensive care units. Intensive Crit Care Nurs, 2005. 21(5): p. 284-301.

73. van Oostveen, C.J., et al., Explaining the amount of care needed by hospitalised surgical patients: a prospective time and motion study. BMC Health Serv Res, 2013. 13: p. 42.

74. Driscoll, D.M., Burn dressings: a critical indicator for patient care classification in burn units. Mil Med, 1991. 156(12): p. 654-7.

75. de Jong, A.E., J. Leeman, and E. Middelkoop, Development of a nursing workload measurement instrument in burn care. Burns, 2009. 35(7): p. 942-8. 
76. Helmer, F.T., Patient classification systems in burn care. J Burn Care Rehabil, 1986. 7(6): p. 511-20.

77. Ravat, F., et al., Working time and workload of nurses: the experience of a burn center in a high income country. Burns, 2014. 40(6): p. 1133-40.

78. Ludvigsson, J.F., et al., External review and validation of the Swedish national inpatient register. BMC Public Health, 2011. 11: p. 450.

79. Ludvigsson, J.F., et al., The Swedish personal identity number: possibilities and pitfalls in healthcare and medical research. Eur J Epidemiol, 2009. 24(11): p. 659-67.

80. Hjortso, E., et al., The nursing care recording system. A preliminary study of a system for assessment of nursing care demands in the ICU. Acta Anaesthesiol Scand, 1992. 36(7): p. 6104.

81. Charlson, M.E., et al., A new method of classifying prognostic comorbidity in longitudinal studies: development and validation. J Chronic Dis, 1987. 40(5): p. 373-83.

82. Sundararajan, V., et al., New ICD-10 version of the Charlson comorbidity index predicted inhospital mortality. J Clin Epidemiol, 2004. 57(12): p. 1288-94.

83. Rehou, S., et al., The influence of substance misuse on clinical outcomes following burn. Burns.

84. Fischer, J.E., L.M. Bachmann, and R. Jaeschke, $A$ readers' guide to the interpretation of diagnostic test properties: clinical example of sepsis. Intensive Care Medicine, 2003. 29(7): p. 1043-1051.

85. Palmu, R., et al., Mental disorders among acute burn patients. Burns, 2010. 36(7): p. 1072-9.

86. Palmu, R., et al., Alcohol use and smoking in burn patients at the Helsinki Burn Center. Burns, 2017.

87. Heng, J.S., et al., Revised Baux Score and updated Charlson comorbidity index are independently associated with mortality in burns intensive care patients. Burns, 2015. 41(7): p. $1420-1427$.

88. Knowlin, L., et al., The measured effect magnitude of co-morbidities on burn injury mortality. Burns, 2016. 42(7): p. 1433-1438.

89. Ulvik, A., T. Wentzel-Larsen, and H. Flaatten, Trauma patients in the intensive care unit: short-and long-term survival and predictors of 30-day mortality. Acta Anaesthesiol Scand, 2007. 51(2): p. 171-7.

90. Laupland, K.B., et al., Long-term mortality outcome of victims of major trauma. Injury, 2010. 41(1): p. 69-72. 
91. Callcut, R.A., et al., Discovering the truth about life after discharge: Long-term trauma-related mortality. J Trauma Acute Care Surg, 2016. 80(2): p. 210-7.

92. Bickenbach, J., et al., Outcome and mortality risk factors in long-term treated ICU patients: a retrospective analysis. Minerva Anestesiol, 2011. 77(4): p. 427-38.

93. Criddle, L.M., 5-year survival of geriatric patients following trauma center discharge. Adv Emerg Nurs J, 2009. 31(4): p. 323-36.

94. Sheridan, R.L., et al., Long-term outcome of children surviving massive burns. JAMA, 2000. 283(1): p. 69-73.

95. Escolas, S.M., et al., Postdischarge Cause-of-Death Analysis of Combat-Related Burn Patients. J Burn Care Res, 2017. 38(1): p. e158-e164.

96. Pompermaier, L., et al., Long-term survival after burns in a Swedish population. Burns, 2016.

97. Nitzschke, S., et al., Long term mortality in critically ill burn survivors. Burns, 2017. 43(6): p. 1155-1162.

98. Moi, A.L., E. Haugsmyr, and H. Heisterkamp, Long-Term Study Of Health And Quality Of Life After Burn Injury. Ann Burns Fire Disasters, 2016. 29(4): p. 295-299.

99. Chen, M.C., et al., The impact of inhalation injury in patients with small and moderate burns. Burns, 2014. 40(8): p. 1481-6.

100. Swedish National Board of Health and Welfare. Open access database. http://www.socialstyrelsen.se/publikationer2016/2016-8-3. Accessed September 2017. .

101. Krishnan, P., et al., Cause of death and correlation with autopsy findings in burns patients. Burns, 2013. 39(4): p. 583-8.

102. Kallinen, O., et al., Multiple organ failure as a cause of death in patients with severe burns. J Burn Care Res, 2012. 33(2): p. 206-11.

103. Pompermaier, L., et al., Burned patients who die from causes other than the burn affect the model used to predict mortality: a national exploratory study. Burns, 2017.

104. Cassidy, J.T., et al., Developing a burn injury severity score (BISS): adding age and total body surface area burned to the injury severity score (ISS) improves mortality concordance. Burns, 2014. 40(5): p. 805-13.

105. Jeschke, M.G., et al., Threshold age and burn size associated with poor outcomes in the elderly after burn injury. Burns, 2016. 42(2): p. 276-81.

106. Albornoz, C.R., et al., Burns are more aggressive in the elderly: proportion of deep burn area/total burn area might have a role in mortality. Burns, 2011. 37(6): p. 1058-61.

107. Jeschke, M.G., et al., Pathophysiologic response to burns in the elderly. EBioMedicine, 2015. 2(10): p. 1536-1548. 
108. Riedlinger, D.I., et al., Scald burns in children aged 14 and younger in Australia and New Zealand-an analysis based on the Burn Registry of Australia and New Zealand (BRANZ). Burns, 2015. 41(3): p. 462-8.

109. Olawoye, O.A., et al., Demographic characteristics and prognostic indicators of childhood burn in a developing country. Burns, 2014. 40(8): p. 1794-8.

110. Kritsotakis, G., et al., Gender differences in the prevalence and clustering of multiple health risk behaviours in young adults. J Adv Nurs, 2016. 72(9): p. 2098-113.

111. Bosque-Prous, M., et al., Gender differences in hazardous drinking among middle-aged in Europe: the role of social context and women's empowerment. Eur J Public Health, 2015. 25(4): p. 698-705.

112. Lobo, E., et al., Gender differences in the incidence of and risk factors for hip fracture: A 16year longitudinal study in a southern European population. Maturitas, 2017. 97: p. 38-43.

113. Denton, M., S. Prus, and V. Walters, Gender differences in health: a Canadian study of the psychosocial, structural and behavioural determinants of health. Social Science \& Medicine, 2004. 58(12): p. 2585-2600.

114. Saikia, N., Moradhvaj, and J.K. Bora, Gender Difference in Health-Care Expenditure: Evidence from India Human Development Survey. PLoS One, 2016. 11(7): p. e0158332.

115. Teunissen, T.A.M., M.E. Rotink, and A.L.M. Lagro-Janssen, Gender differences in quality of care experiences during hospital stay: A contribution to patient-centered healthcare for both men and women. Patient Education and Counseling, 2016. 99(4): p. 631-637.

116. Rubenson Wahlin, R., et al., Do male and female trauma patients receive the same prehospital care?: an observational follow-up study. BMC Emerg Med, 2016. 16: p. 6.

117. Hausmann, R., et al. The global gender gap report 2009. 2009. World Economic Forum.

118. Petrie A., Sabin C. Medical Statistics at a Glance. 3rd edition. 2009, Wiley-Blackwell.

119. Powell, J.T. and M.J. Sweeting, Retrospective Studies. Eur J Vasc Endovasc Surg, 2015. 50(5): p. 675.

120. Mason, S.A., et al., The accuracy of burn diagnosis codes in health administrative data: $A$ validation study. Burns, 2017. 43(2): p. 258-264.

121. Ong, A.W., et al., Unexpected findings in trauma patients dying in the intensive care unit: results of 153 consecutive autopsies 1 1No competing interests declared. Journal of the American College of Surgeons, 2002. 194(4): p. 401-406.

122. Kallinen, O., et al., Comparison of premortem clinical diagnosis and autopsy findings in patients with burns. Burns, 2008. 34(5): p. 595-602. 
123. Lindstrom, P., L. Janzon, and N.H. Sternby, Declining autopsy rate in Sweden: a study of causes and consequences in Malmo, Sweden. J Intern Med, 1997. 242(2): p. 157-65. 


\section{Papers}

The papers associated with this thesis have been removed for copyright reasons. For more details about these see:

http:// urn.kb.se/ resolve?urn=urn:nbn:se:liu:diva-142897 